Eliezer Francisco de Santana Junior

\title{
AVALIAÇÃO DO EFEITO DE EXOSSOMOS NA ADERÊNCIA E REPLICAÇÃO DE CÉLULAS TUBULARES HUMANAS EM MATRIZ DESCELULARIZADA
}

\author{
Dissertação apresentada à Faculdade \\ Israelita de Ciências da Saúde Albert \\ Einstein para obtenção do Título de Mestre \\ em Ciências da Saúde.
}

São Paulo 
Eliezer Francisco de Santana Junior

\title{
AVALIAÇÃO DO EFEITO DE EXOSSOMOS NA ADERÊNCIA E REPLICAÇÃO DE CÉLULAS TUBULARES HUMANAS EM MATRIZ DESCELULARIZADA
}

\author{
Dissertação apresentada à Faculdade \\ Israelita de Ciências da Saúde Albert \\ Einstein para obtenção do Título de Mestre \\ em Ciências da Saúde. \\ Orientadora: Profa. Dra. Nádia Karina \\ Guimarães de Souza
}


S232a

Santana Junior, Eliezer Francisco de

Avaliação do efeito de exossomos na aderência e replicação de células tubulares humanas em matriz descelularizada / Eliezer

Francisco de Santana Junior. -- São Paulo, 2018.

xiii, $43 \mathrm{f}$.

Dissertação (Mestrado) - Faculdade Israelita de Ciências da Saúde Albert Einstein. Instituto Israelita de Ensino e Pesquisa Albert Einstein. Programa de Pós-Graduação em Ciências da Saúde.

Título em inglês: Evaluation of the effect of exosomes on adherence and replication of human tubular cells in decellularized matrix.

1. Insuficiência renal crônica. 2. Terapia baseada em transplante de células e tecidos. 3. Exossomos. 4. Recelularização.

NLM - WJ 342

Elaborada pelo Sistema Einstein Integrado de Bibliotecas 
FACULDADE ISRAELITA DE CIÊNCIAS DA SAÚDE ALBERT EINSTEIN

Coordenador do Curso de Pós-Graduação: Prof. Dr. Luiz Vicente Rizzo 
Eliezer Francisco de Santana Junior

\title{
AVALIAÇÃO DO EFEITO DE EXOSSOMOS NA ADERÊNCIA E REPLICAÇÃO DE CÉLULAS TUBULARES HUMANAS EM MATRIZ DESCELULARIZADA
}

Presidente da banca: Profa. Dra. Nádia Karina Guimarães de Souza

\author{
BANCA EXAMINADORA
}

Membros titulares:

Profa. Dra. Erika Bevilaqua Rangel

Prof. Dr. Humberto Dellê

Profa. Dra. Luciana Cavalheiro Marti

Membros suplentes:

Prof. Dr. Antonio da Silva Novaes

Prof. Dr. Oscar Fernando Pavão

Aprovada em: 10/12/2018 


\section{Dedicatória}

Ao meu querido avô, Auto Santana, que sempre desejou que eu fosse grande. 


\section{Agradecimentos}

Gostaria de agradecer primeiramente a Deus por ter me proporcionado o dom da vida para que pudesse desenvolver este trabalho $\mathrm{e}$ procurasse entender como tudo funciona de forma clara e construtiva.

Aos meus pais, Eliezer e Ana, que vem sempre me incentivando a batalhar e alcançar os meus objetivos.

À minha super orientadora, Dra. Nádia, que com a maior compreensão e paciência do mundo deu todo o suporte necessário para a pesquisa dar certo, sempre com sua marca de pensamento positivo.

À Dra. Anna Carla Goldberg, graças a ela, eu pude ter a oportunidade de chegar neste importante momento de minha vida.

Aos colaboradores Fernanda Rocha, Antônio Novaes e Aline Silva pelo apoio incondicional ao longo do desenvolvimento dos experimentos.

À super equipe do CETEC, Lucas, Marcos, Flávio, por toda a atenção, suporte e espírito de equipe.

À equipe Einstein, Thiago Aloia, Marta, Edicléia, por me ensinarem a saber lidar com situações de imprevisto e estarem ali para ajudar sempre quando necessário.

Aos meus colegas do Hospital Israelita Albert Einstein, Bruno, Vanessa, Helena, Katiane, Rafaela, que estavam presentes em todos os momentos auxiliando e dando palavras de ânimo.

E em especial, à uma grande amiga que conheci na cidade de New York e que graças a ela, soube que o Instituto Israelita de Ensino e Pesquisa oferecia este curso de mestrado. Muito obrigado Mirian Krystel! 
Agradecimentos especiais

Agradeço à FAPESP por dar todo o apoio financeiro para a realização do projeto de pesquisa. Processo: 2016/16613-0. 


\section{Sumário}

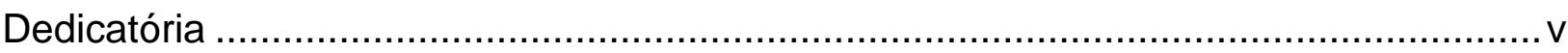

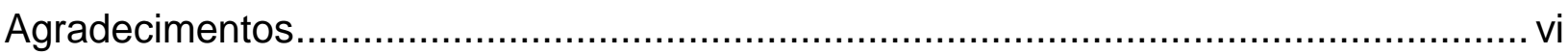

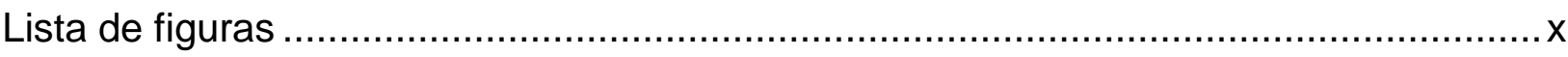

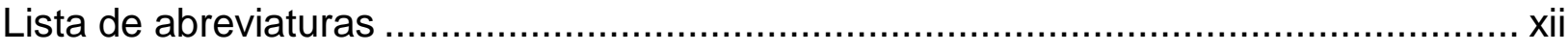

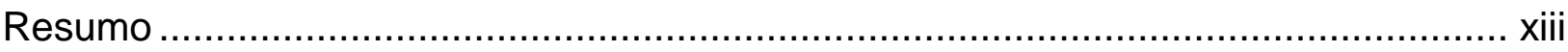

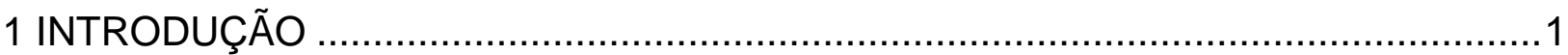

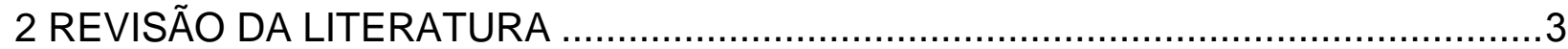

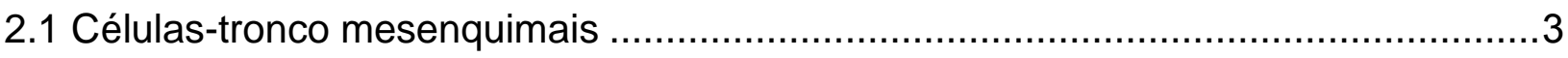

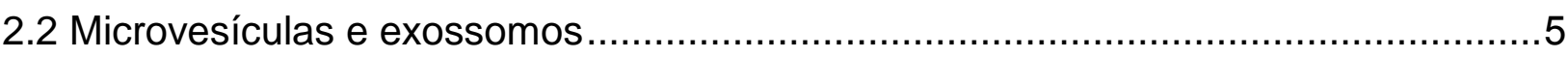

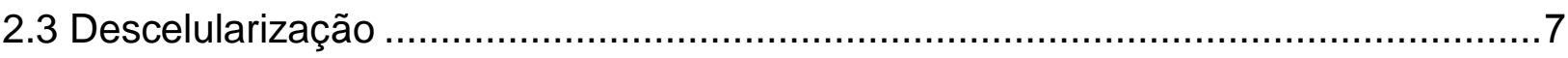

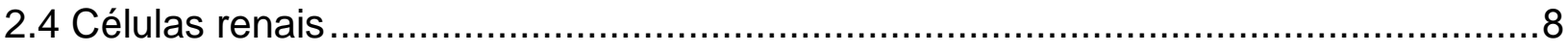

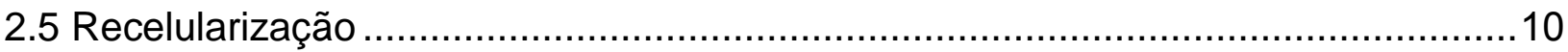

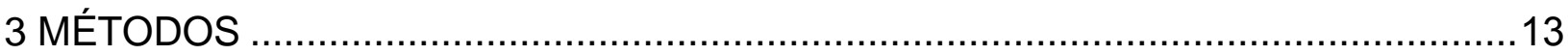

3.1 Obtenção de células renais humanas .........................................................13

3.2 Caracterização de células renais humanas .................................................. 14

3.3 Isolamento e caracterização de células mesenquimais de cordão e seus exossomos .14

3.3.1 Isolamento e caracterização de células mesenquimais do cordão umbilical ........14

3.3.2. Obtenção dos exossomos ..................................................................... 15

3.3.2.1 Coleta do meio de cultura para extração dos exossomos .............................15

3.3.2.2 Extração e purificação dos exossomos ..................................................16

3.3.2.3 Identificação das proteínas em exossomos ............................................. 16

3.4 Descelularização de fragmentos de matriz renal de porco .................................. 16

3.5 Avaliação de aderência em tecido descelularizado ........................................17

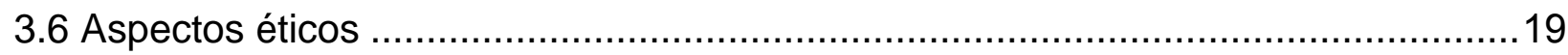

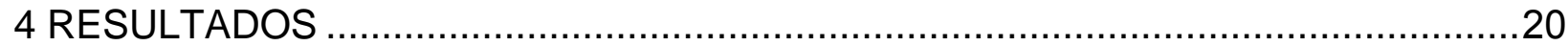

4.1 Obtenção e caracterização das células renais humanas .....................................20

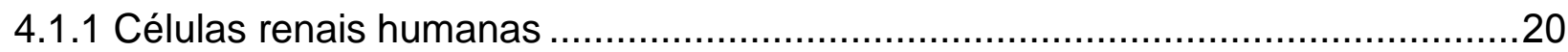

4.2 Isolamento e caracterização de células mesenquimais de cordão e obtenção de microvesículas e exossomos.......................................................................... 21

4.2.1 Obtenção de microvesículas e exossomos ................................................22 


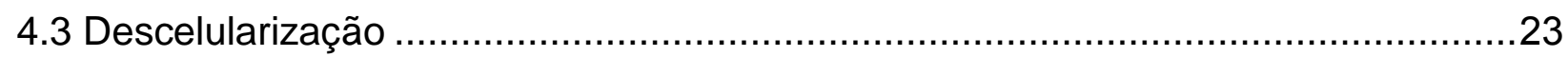

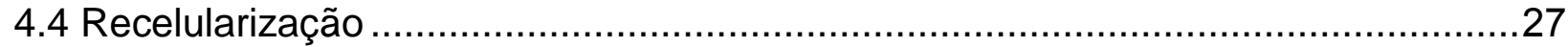

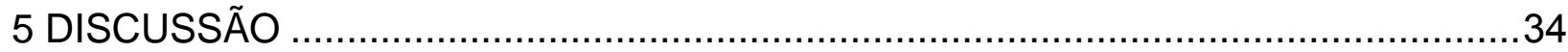

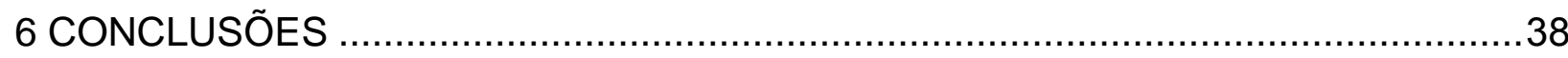

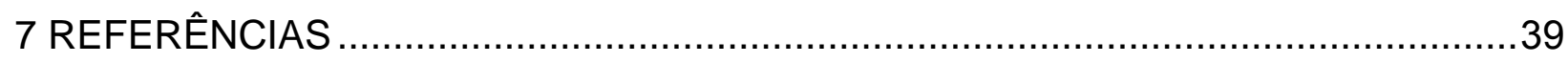

Abstract 


\section{Lista de figuras}

Figura 1. Esquema das etapas experimentais desenvolvidas ...............................13

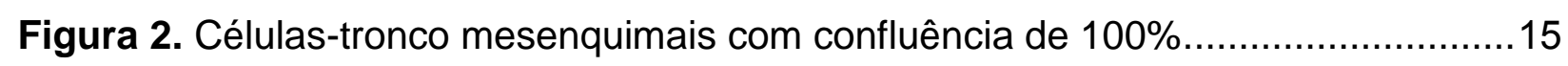

Figura 3. Esquema da dinâmica da descelularização no biorreator .............................17

Figura 4. Estratégias de experimento para regeneração renal ...................................18

Figura 5. Gráficos ilustrativos dos experimentos de caracterização de exossomos ....22

Figura 6. Exossomos em tamanho e dimensões diferentes encontrados pela análise no

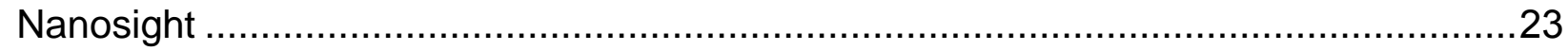

Figura 7. Western blot para CD63 e CD81 em exossomos produzidos por células

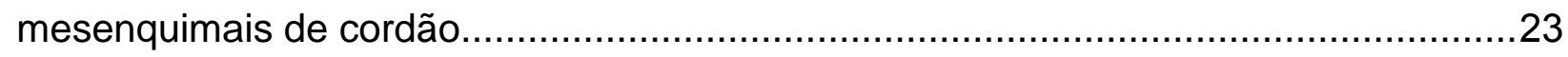

Figura 8. Biorreator customizado em atividade....................................................24

Figura 9. Do lado esquerdo (A), o rim em processo de descelularização; e do lado

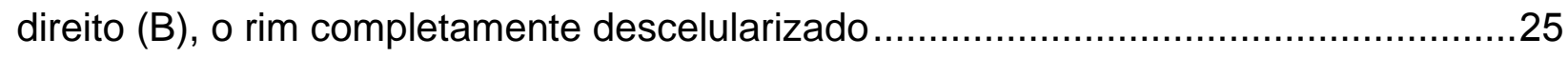

Figura 10. Tecido descelularizado do rim do porco com estrutura vascular preservada

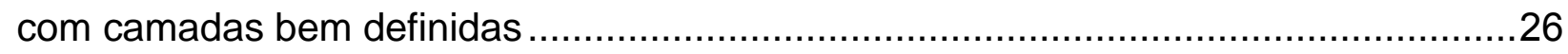

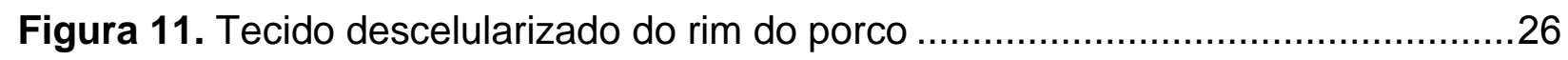

Figura 12. Grupo 1 - Células renais humanas em matriz descelularizada após 9 dias

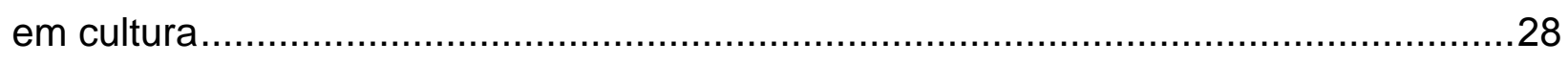

Figura 13. Grupo 2 - Exossomos inseridos junto à matriz descelularizada e as células

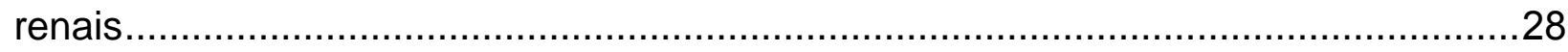

Figura 14. Grupo 3 - Fator de crescimento de hepatócitos com células e matriz ........29 Figura 15. Grupo 4 - Associação de exossomos e fator de crescimento de hepatócitos à matriz e células renais

Figura 16. Grupo 5 - Fator de crescimento transformador beta em cultura de células renais e matriz

Figura 17. Grupo 6 - Exossomos e fator de crescimento transformador beta em cultura de células renais e matriz. .31

Figura 18. Grupo 1 - Morte de células renais humanas evidenciada em matriz

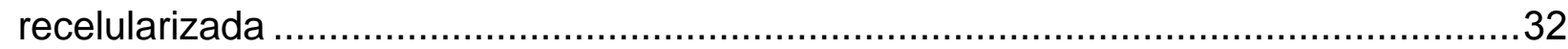

Figura 19. Grupo 2 - Matriz recelularizada com menor taxa de morte celular...............32

Figura 20. Grupo 3 - Pequena quantidade de células apoptóticas com o fator de crescimento de hepatócitos inserido no meio..... .32 
Figura 21. Grupo 4 - Ausência de morte celular na matriz com fator de crescimento de

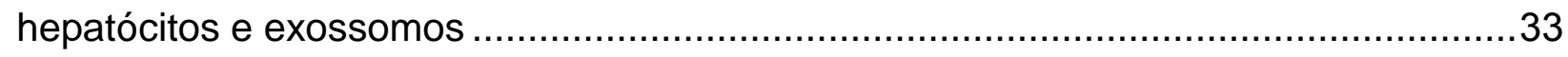

Figura 22. Grupo 5 - Pouca recelularização e nenhuma célula em processo de apoptose sob a influência de fator de crescimento transformador beta 33

Figura 23. Grupo 6 - Elevado número de células apoptóticas no ensaio com fator de crescimento transformador beta exossomos e baixo índice de morte celular na sua repetição. .33 


\section{Lista de abreviaturas}

All Angiotensina II

AGE Produtos de glicosilação avançada (Advanced glycation and products)

DRC Doença renal crônica

FGF Fator de crescimento de fibroblastos (Fibroblast growth factor)

HGF Fator de crescimento de hepatócitos (Hepatocyte growth factor)

IGF1 Fator de crescimento derivado de insulina 1 (Insulin growth factor 1)

PBS Tampão fosfato salino (Phosphate buffered saline)

ROS Espécies reativas de oxigênio (Reactive oxygen species)

SDS Dodecil sulfato de sódio (Sodium dodecyl sulfate)

TFG Taxa de filtração glomerular

TGF- $\beta \quad$ Fator transformador de crescimento beta (Transforming growth factor beta) 


\section{Resumo}

Introdução: A doença renal crônica é um problema que tem crescido mundialmente nas últimas décadas. O rim tem a capacidade de se regenerar quase que completamente após insultos. Entretanto, em algumas situações ocorre progressiva fibrose com perda funcional. Alguns fatores de crescimento foram descritos, como o fator de crescimento de hepatócitos, um importante regulador de recuperação de células renais. Estudos recentes sugerem um mecanismo de comunicação celular entre células-tronco mesenquimais e células epiteliais renais sendo descrita a presença do fator de crescimento de hepatócitos no interior dos exossomos, sugerindo que este seja um mecanismo estimulatório para regeneração tecidual. Objetivo: Avaliar o efeito de exossomos, secretados por células mesenquimais de cordão umbilical, na aderência e proliferação de células primárias renais cultivadas em matriz renal descelularizada. Métodos: A metodologia foi realizada em etapas: caracterização de células renais humanas em cultura; obtenção de exossomos a partir de células-tronco mesenquimais de cordão umbilical e sua caracterização por western blot (CD63 e CD81); e descelularização de rim porcino com dodecil sulfato de sódio. A recelularização foi realizada comparando-se o efeito de exossomos na presença dos fatores prócrescimento, o fator de crescimento de hepatócitos; e pró-fibrose, o fator de crescimento transformador beta; e isoladamente. Resultados: Células renais humanas apresentaram crescimento satisfatório em cultura. $O$ tecido renal porcino descelularizado preservou a arquitetura. Exossomos de células-tronco mesenquimais de cordão umbilical foram secretados e caracterizados positivamente para CD63 e CD81 em western blot. A recelularização, demonstrada pela aderência de células renais, ocorreu em todos os experimentos. Quando avaliamos a morte celular através da caspase 3 , a associação do fator de crescimento transformador e exossomos determinou maior porcentagem de células apoptóticas. Nos demais experimentos a presença dos exossomos determinou menor morte celular. Conclusão: Exossomos produzidos por células-tronco mesenquimais de cordão umbilical humano, determinaram menor morte celular em recelularização de matriz com células renais humanas. 


\section{INTRODUÇÃo}

A doença renal crônica (DRC) é considerada uma patologia de grande prevalência e é definida pela deterioração das funções renais, levando à sinais e sintomas de uremia. A uremia se caracteriza pelo acúmulo de substâncias tóxicas no sangue. ${ }^{(1)}$

A DRC é associada a outras múltiplas comorbidades, aumentando o risco de morte e os custos para seus tratamentos. ${ }^{(2)}$ Diabetes, hipertensão, obesidade e dislipidemia são doenças comuns, e podem originar a DRC. ${ }^{(3)}$ Existe uma associação entre o grau de lesão tubulointersticial e a velocidade de progressão da DRC. Segundo a National Kidney Foundation, 30 milhões de norte-americanos estão em situação de risco para desenvolverem a doença. Em um levantamento realizado pelo United States Renal Data System, no ano de 2016 foi reportado mais de 100.000 mortes de portadores da doença, que envolveu pessoas de todas as idades e acometidas por doenças ligadas à DRC..$^{(4)}$ No Brasil mais de 120.000 pacientes estão em tratamento dialítico ${ }^{(5)}$ e estima-se que até 2030 cerca de 5,4 milhões de pacientes receberão algum tipo de tratamento para DRC. ${ }^{(6)}$ A progressão da maioria das doenças renais está associada às mudanças patológicas no interstício renal. Estudos realizados em biópsias renais humanas apontaram uma associação entre fibrose no interstício e a piora da função renal..$^{(7-9)}$

Inúmeros fatores de crescimento, citocinas e hormônios são responsáveis pela regulação deste processo. Entretanto, o mais importante fator próapoptótico no rim é o fator transformador de crescimento beta (TGF- $\beta$ - transforming growth factor beta). O TGF- $\beta$ inicia e promove a manutenção dos processos de fibrose através da ativação de vias de sinalização e fatores de transcrição. ${ }^{(10)}$ De fato, Baczkowska et al. ${ }^{(11)}$ descreveram a correlação positiva dos níveis séricos de TGF- $\beta$ e a fibrose em enxertos renais. Outras moléculas tais como produtos de glicosilação avançada (AGE - Advanced glycation and products), espécies reativas de oxigênio (ROS - reactive oxygen species), angiotensina II (All), e condição de hipóxia também favorecem o processo fibrótico. ${ }^{(12-19)}$

Com o objetivo de substituir ou regenerar tecidos humanos, a medicina regenerativa não vem medindo esforços para aprimorar cada vez mais as técnicas para recelularização. A engenharia de tecidos consiste em três principais 
bases: as células, as moléculas sinalizadoras e a matriz, e estes dependem um do outro para funcionar em conjunto harmônico, atuando na regulação do crescimento celular e no desenvolvimento do tecido. Logo, a otimização desses processos envolve a restauração e o restabelecimento das funções de tecidos e órgãos humanos. ${ }^{(20-22)}$

Levando em conta a necessidade de novas terapêuticas para o tratamento desta doença com alta prevalência e índices crescentes de mortalidade, este estudo tem por objetivo recelularizar, matriz porcina descelularizada, com células renais humanas utilizando exossomos com o fator de crescimento de hepatócitos (HGF - hepatocyte growth factor), extraídos de células mesenquimais de cordão umbilical humano, comparando aderência e apoptose das células expostas aos exossomos com fatores de crescimento sintéticos.

\subsection{Objetivos}

1. Avaliar o impacto dos exossomos na recelularização renal;

2. Verificar a aderência de células renais humanas em matriz acelular;

3. Avaliar impacto dos exossomos na morte celular. 


\section{REVISÃO DA LITERATURA}

\subsection{Células-tronco mesenquimais}

A célula-tronco mesenquimal é um tipo celular indiferenciado que se caracteriza por seu poder multipotente através da capacidade de produção de diferentes celulares essenciais para um processo de reparação, como células renais, epiteliais, cardíacas, entre outras. Tecido adiposo, fígado, baço, timo, placenta, geléia de Wharton, cérebro, pulmão, polpa dentária e amígdala palatina são locais que normalmente podem estar presentes, mas concentram-se principalmente na medula óssea. As células-tronco mesenquimais também são encontradas na região endotelial do cordão umbilical, o qual é a fonte das células deste estudo. ${ }^{(23,24)}$

A identificação destas células ocorreu pela primeira vez na Rússia, por Friendeinstein e atualmente elas vêm sendo utilizadas devido à sua disponibilidade, viabilidade e plasticidade em todo o mundo. ${ }^{(24)}$ Segundo a Sociedade Internacional de Terapia Celular, as células-tronco mesenquimais podem ser caracterizadas por três critérios: a propriedade de aderência em cultura sob condições padronizadas; a expressão de CD105, CD90 e CD73, bem como a não expressão de CD34, CD45, CD14, CD79a; e a potência de diferenciação para adipócitos, condroblastos e osteoblastos in vitro. ${ }^{(25)}$

A característica de plasticidade vem conferindo à célula-tronco mesenquimal um espaço importante no campo da medicina regenerativa como uma ferramenta promissora nas pesquisas ligadas à terapia celular. Este tipo celular tem a capacidade de ser expandida em até 40 gerações mantendo o seu poder de autorenovação e diferenciação em diferentes tipos celulares, apesar da redução do seu poder mitótico e o aumento das chances de mutação ao decorrer de cada geração cultivada. ${ }^{(24,26)}$

A capacidade de diferenciação das células-tronco mesenquimais em diferentes linhagens celulares ocorre por diversos estímulos, entre os quais está a interação célula-célula, em que substâncias secretadas por células vizinhas propiciam à diferenciação; divisão celular, em que células se tornam diferentes pelo conteúdo específico que carregou após uma divisão assimétrica; e regulação gênica, onde a 
expressão ou não de determinados genes vão indicar qual tipo celular aquela célula se tornará. (24)

No processo de reparação tecidual outra característica importante das células-tronco mesenquimais é a expressão de determinadas moléculas bioativas que estão diretamente ligadas à resposta inflamatória, angiogênese e mitose das células envolvidas nessa reparação, como moléculas de adesão, citocinas e receptores para fatores de crescimento, sendo estes últimos essenciais para a interação com o HGF e o TGF- $\beta$ que são utilizados no experimento. ${ }^{(26)}$

Quando o tecido em questão entra em contato com as células-tronco mesenquimais, há a liberação de fatores como o HGF, o TGF- $\beta$, interleucinas, prostaglandinas e algumas enzimas que atuam diretamente no sistema imune. ${ }^{(27)}$ Essas moléculas bioativas estão diretamente relacionadas com o processo de reparação tecidual e assumem importantes funções como ter o papel de evitar a apoptose das células tecido-específicas, contribuir na melhora da angiogênese, produzir efeito imunomodulatório nas células do sistema imunológico e promover a quimiotaxia às células que estão comprometidas. ${ }^{(28)}$ De acordo com o nível de comprometimento do tecido, o restabelecimento das suas características anátomofuncionais originais, podem ser retomadas de forma mais breve ou complexa e apesar dos mecanismos de imunossupressão sobre a inflamação e dos mecanismos de rejeição dessas células não estarem completamente claros, elas vem gradualmente se tornando cada vez mais alvos de estudos na área terapêutica. ${ }^{(26,29)}$

O crescimento gradual da utilização de células-tronco mesenquimais é visto no aperfeiçoamento do processo de reparo em tecidos lesados, sobretudo com a utilização de moléculas secretadas por essas células, como os exossomos. Os exossomos têm sido amplamente investigados e acredita-se que estão envolvidos em muitos processos fisiológicos e patológicos. Sendo assim, o isolamento e a identificação destas vesículas extracelulares oriundas das células-tronco mesenquimais, tem se tornado uma interessante alternativa para terapias celulares com plausíveis aplicações em um futuro próximo. ${ }^{(24)}$ 


\subsection{Microvesículas e exossomos}

Recentemente foi descrita a presença de microvesículas nas comunicações célula-célula nas interações de células mesenquimais. Essa observação suporta o efeito parácrino das mesmas microvesículas ou exossomos que são vesículas membranosas extracelulares importantes no papel da comunicação intercelular de longa distância. Normalmente, eles medem em torno de 30-140nm de diâmetro e se originam por brotamento da membrana plasmática. ${ }^{(30,31)}$

Os exossomos tem a capacidade de se difundir por fluidos corporais, conseguindo entregar mensagens à maioria das células do organismo com êxito. As mensagens carregadas pelos exossomos acontecem na forma de DNA, RNA ou proteínas. Em condições fisiológicas e patológicas, ocorre a liberação de exossomos. A membrana das microvesículas, assim como a dos exossomos, pode apresentar e carrear vários fatores bioativos além do conteúdo molecular transportado em seu interior. ${ }^{(30,31)} \mathrm{Em} 2007$, Kunter et al. afirmaram que a recuperação das células tubulares renais na lesão aguda se dá em parte por ação de células com características mesenquimais de maneira parácrina, mas também por ação endócrina. ${ }^{(32)}$

A eficácia da administração de exossomos derivadas de células mesenquimais na regeneração tecidual renal foi semelhante à obtida com o uso das próprias células, o que indica que os exossomos são mediadores importantes e críticos nas interações celulares. ${ }^{(30)}$ Microvesículas com padrões de RNA participam da troca de informações genéticas entre células. Recentemente, também foi demonstrado que microvesículas de células mesenquimais transportam mRNA, microRNA e fatores transcricionais para tecidos lesados, logo os exossomos possuem a mesma função. ${ }^{(33)}$

Em estudo recente, demonstrou-se a relação entre a produção de HGF e maior agressividade de células tumorais. Entre os fatores transcricionais, mRNA e microRNAs, produzidos por células mesenquimais, o HGF foi descrito como presente em microvesículas que auxiliaram na regeneração renal. Neste mesmo estudo demonstrou-se que a produção de HGF é um fator crucial para acelerar a recuperação e proliferação de células tubulares após insulto. ${ }^{(34)}$

Em modelos animais com DRC, as terapias celulares têm mostrado resultados promissores. Kunter et al. administraram células mesenquimais em modelo de glomerulonefrite crônica e obtiveram melhora de função renal. Entretanto, outros 
autores, em modelo de nefrectomia unilateral seguida de indução de nefrite e transferência de células mesenquimais observaram melhora de função em 10 e 60 dias, porém a análise histológica mostrou acúmulo de adipócitos com depósitos de colágeno tipo I, III e IV e presença de a-actina nos glomérulos. ${ }^{(32)}$ Estes resultados mostram os riscos de diferenciação indesejada de células progenitoras. Kim et al. usaram como modelo para DRC doença renal crônica a nefrectomia de cinco sextos do órgão e administraram abaixo da cápsula renal células precursoras obtidas de rim fetal. Houve reconstrução de tecido e sobrevida das células comprovadas após 10 semanas. ${ }^{(35)}$

Assim como as microvesículas, os exossomos também podem facilitar a repopulação celular renal de maneira eficiente sem a necessidade de utilizar células íntegras para a transferência, evitando diferenciação indesejada e/ou reações decorrentes da necrose ou apoptose. Camundongos com necrose generalizada tratados com microvesículas, obtiveram total recuperação de lesões tubulares após 15 dias, logo, a longo prazo, exossomos de células-tronco do próprio paciente poderiam ser utilizadas minimizando riscos de reações imunes e infecções. Além disso, não seria necessário o uso de drogas imunossupressoras. ${ }^{(31)}$

Ao contemplar terapias celulares para recuperação de lesões renais, há vários aspectos que devem ser considerados para um melhor entendimento e desenvolvimento da técnica em si. Entre eles estão:

1. As células epiteliais renais são especializadas e altamente diferenciadas. O uso de células diferenciadas diminuiria o risco de formação de tumores e de diferenciação "incorreta" (como ocorre com a transferência de célulastronco embrionárias);

2. Células-tronco e progenitoras são quimioatraídas para as áreas de lesão;

3. Células mesenquimais são parte do nicho endosteal e vascular da medula óssea, onde contribuem para renovação, maturação e recrutamento de célulastronco hematopoiéticas. Constituem uma população heterogênea de células capazes de se diferenciar em diferentes linhagens. A possibilidade de cultivar e expandir células autólogas é muito atraente, uma vez que permitiria uma terapia celular mais segura (menor risco de formação tumoral), função mais rápida (células já diferenciadas) e sem necessidade de imunossupressão. ${ }^{(36)}$ 


\subsection{Descelularização}

Atualmente a descelularização é considerada uma das mais importantes e promissoras técnicas de regeneração de órgãos e tecidos. A descelularização pode ser definida como o processo de remoção de material celular da matriz extracelular das células nativas e dos materiais genéticos, como DNA, mantendo as características estruturais, bioquímicas e biomecânicas de tecidos biológicos ou órgãos. Este procedimento pode ser executado por processo químico e enzimático, físico ou por métodos combinatórios. Cada estratégia possui seus benefícios e suas desvantagens, e para a escolha da melhor técnica a ser usada devem ser verificadas as propriedades estruturais e mecânicas que uma matriz possui, como por exemplo, a rigidez e a topografia, para desta forma configurar um ambiente ideal que vem a influenciar diretamente no crescimento e diferenciação celular específicos. ${ }^{(37)}$

Uma das técnicas que tem sido amplamente utilizada é o uso do dodecil sulfato de sódio (SDS - sodium dodecyl sulfate) que é um detergente aniônico com a capacidade de lisar células e solubilizar componentes citoplasmáticos. ${ }^{(38)}$ O SDS tem sido bem-sucedido em várias aplicações de descelularização por proporcionar a remoção mais completa de células, bem como de qualquer material genético sem causar danos. Dessa forma, uma matriz descelularizada poderia ser repovoada com novas células obtendo resultados de sucesso já demonstrados em alguns artigos que ratificam a técnica de descelularização em tecidos e órgãos como vasos sanguíneos, válvula cardíaca, músculo, córnea, traqueia, esôfago, bexiga urinária, intestino, fígado, pulmão, coração e até mesmo o rim. . $^{(37,39)}$

Pela cadeia evolutiva, alguns animais possuem órgãos que compartilham de estruturas anatômicas e fisiológicas semelhantes ao do ser humano. Entre eles, o porco possui um rim que além de demonstrar características parecidas similares ao humano como tamanho e peso, a atividade renal é bem próxima ao dos rins humanos, o que leva a constatação que este é um modelo ideal para o processo de descelularização. Além disso, sua obtenção é fácil e econômica. 


\subsection{Células renais}

O desenvolvimento renal é geneticamente regulado e controla a divisão celular e a proliferação do tecido. Existem fatores de crescimento tais como o fator de crescimento de fibroblastos (FGF - fibroblast growth factor), o TGF- $\beta$ e o HGF, que são polipeptídeos responsáveis pela transmissão de sinais intracelulares e são essenciais para que ocorra a atividade de formação dos rins de forma adequada. ${ }^{(40)}$

Os néfrons são um emaranhado de túbulos microscópicos compostos por uma única camada celular. ${ }^{(41,42)}$ Eles podem chegar à mais de um milhão de unidades e exercem importante papel no bom desempenho da função renal, ${ }^{(41,43)}$ sendo que $80 \%$ destes se localizam na região do córtex renal e os outros $20 \%$ na região da medula. O néfron consiste em corpúsculo renal, túbulo proximal, alça de Henle, túbulo distal e ducto coletor, porém devido às características anatômicas e funcionais diferentes nestes componentes, considera-se que o néfron possua 14 setores diferentes e cada um destes componentes são interligados entre si como um sistema, o chamado sistema renal. ${ }^{(41)}$

São encontrados cerca de 30 diferentes tipos de celulares renais, cada uma com sua morfologia e funcionalidade específicas. Quando algumas dessas células possuem algumas dessas características alteradas, pode-se afirmar que há o início ou uma presente lesão. No caso da DCR; a lesão pode estar presente por um período igual ou superior a três meses, determinada por anormalidades estruturais ou funcionais, com ou sem diminuição da taxa de filtração glomerular (TFG), evidenciada por alterações histopatológicas ou de marcadores de lesão renal, incluindo valores de ureia e creatinina fora dos padrões normais. ${ }^{(41,44)}$

Entre os tipos celulares mais importantes estão:

1. Células do endotélio do glomérulo que são formados por capilares fenestrados com poros que permitem que a maioria dos componentes do plasma sejam filtrados, constituindo a primeira barreira de filtração; ${ }^{(40,41)}$

2. Células mesangiais possuem feixes similares aos filamentos de actina no seu citoplasma, permitindo a contração e alteração do fluxo sanguíneo por meio de capilares. Se tratando da DRC, uma importante função delas é a secreção de citocinas que são associadas à processos imunes e inflamatórios, portanto quando há qualquer tipo alteração ou interrupção das suas atividades, é visto o desenvolvimento 
de processos patológicos renais. ${ }^{(40,41)}$ A segunda barreira de filtração é constituída por uma camada acelular formada por uma matriz extracelular nomeada por lâmina basal que é formada por glicoproteínas que atua como uma peneira. Ela desempenha a função de reter a maior parte das proteínas do plasma que é filtrado dentro do capilar; ${ }^{(40,41)}$

3. Podócitos são células especializadas que possuem extensões citoplasmáticas longas similares a dedos que se estendem a partir do corpo celular principal, formando a terceira barreira de filtração; ${ }^{(41)}$

4. Células do túbulo proximal são células epiteliais de camada única com polaridade da membrana e junções celulares que permitem a reabsorção de 60 a $80 \%$ de ultrafiltrado; ${ }^{(40,41)}$

5. Células do túbulo distal são células epiteliais de camada única com a particularidade de responder a hormônios. Essa região embora faça 1-5\% da reabsorção do ultrafiltrado, é responsável pelo ajuste fino de sódio, bem como resposta a hormônios e ajuste de cálcio; ${ }^{(40,41,43)}$

6. Células de Alça de Henle são compostas por três porções. A porção fina descendente, ascendente e porção espessa; ${ }^{(41)}$

7. Fibroblastos são responsáveis pela produção de eritropoietina que exercem o controle da função hormonal. ${ }^{(40,41)}$

Diante dos diferentes tipos celulares e da necessidade de sua integridade para que o processo de filtração e reabsorção funcionem adequadamente, fatores de crescimento e citocinas coordenam a manutenção do órgão. ${ }^{(40,41)}$

A indução da síntese destes fatores de crescimento promove a sobrevida e proliferação das células tubulares. Além dos processos de regeneração via células tubulares remanescentes citados acima, células-tronco também são capazes de regenerar tecido renal. ${ }^{(45,46)} \mathrm{O}$ processo regenerativo no rim, assim como em outros órgãos, parece envolver diferenciação e organização celular, visto que alterações no rim são controladas pela proliferação e diferenciação das células parenquimatosas e da matriz extracelular, bem como pela eliminação de alguns tipos celulares por morte celular programada. A substituição de células depende da interação entre células diferentes e entre as células e a matriz extracelular, ressaltando que as caderinas são as principais moléculas de adesão envolvidas na morfogênese dos vertebrados. ${ }^{(47)}$ 
Com a finalidade de elucidar os mecanismos de lesão e reparo nas doenças renais, os pesquisadores têm se utilizado de modelos animais de lesão aguda e de lesão crônica. Estudos recentes mostraram que o papel de reparo após lesão renal aguda é executado principalmente pelas células sobreviventes. ${ }^{(45)}$ As células tubulares epiteliais sobreviventes se desdiferenciam e proliferam repondo as células mortas. ${ }^{(46)}$ De fato, a desdiferenciação é parte integral do processo de reparo e se o estímulo for corretamente regulado, resultará em uma melhor sobrevida, migração e proliferação celular, promovendo a reconstrução tubular. ${ }^{(47)}$ Alguns fatores reparatórios ou estimuladores da síntese de fatores de crescimento de células tubulares, incluindo o HGF, o fator de crescimento derivado de insulina 1 (IGF1 - insulin growth factor 1), o TGF- $\beta$ e o EGF, exercem função parácrina promovendo, desta forma, desdiferenciação celular e regeneração via mecanismos de comunicação célula-célula. ${ }^{(46,48,49)}$

Neste cenário, diferentes tipos celulares têm sido utilizados na tentativa de regeneração tecidual e recuperação de função renal. Foi observado em modelos animais de lesão renal aguda, seguida pela administração de células-tronco de medula óssea, menor grau de lesão histológica e consequente menor acúmulo de escórias nitrogenadas em comparação aos controles não transplantados. ${ }^{(50-52)}$ Por outro lado, animais submetidos à lesão renal aguda por injeção de glicerol, apresentaram melhora da função renal após a administração de células progenitoras epiteliais renais CD24+/CD133+. ${ }^{(53-55)}$

\subsection{Recelularização}

A medicina regenerativa vem conquistando resultados terapêuticos importantes para os pacientes. A DCR é um importante problema de saúde pública no Brasil e no mundo. ${ }^{(20,56,57)}$ Pacientes em estadio terminal da DRC necessitam de terapia renal substitutiva para sobrevivência e a terapia mais comum em nosso meio é a hemodiálise uma vez que existe uma escassez de oferta de órgãos para transplante. Novas técnicas de medicina regenerativa vem sendo buscadas para melhorar a qualidade de vida dos pacientes ${ }^{(58)}$ e para isso inúmeros trials clínicos estão em andamento com o objetivo de novas terapêuticas para DRC. A recelularização é o processo que visa repovoar a matriz natural descelularizada com células de interesse. Para isso é imprescindível investigar os melhores tipos celulares e métodos de 
recelularização. A recelularização já foi descrita em tecidos com tipo celular único como, por exemplo, enxertos de pele ou vasos sanguíneos. Durante o processo de recelularização de tecidos mais espessos ou órgãos inteiros, as células podem ser injetadas diretamente no tecido ou infundidas através da vasculatura do órgão. ${ }^{(20,37)}$

Alguns estudos têm demostrado limitações técnicas na recelularização de tecidos complexos, devido a dificuldade da difusão de suprimentos essenciais para o funcionamento do órgão. No estudo que descreveu a recelularização do fígado, hepatócitos primários demandaram altas concentrações de oxigênio para exercer suas funções metabólicas. Caso esse suprimento seja insuficiente na região mais interna do tecido recelularizado, as células sofrem isquemia. ${ }^{(59)} \mathrm{Na}$ recelularização de válvulas cardíacas, o uso do biorreator influenciou o sucesso da recelularização. ${ }^{(38)}$

A manutenção de estruturas vasculares durante a descelularização, permitiu o transplante de fígado recelularizado em camundongos e a análise póstransplante demonstrou a preservação da estrutura e da função dos hepatócitos com o mínimo de dano isquêmico possível. ${ }^{(59)}$

O pulmão descelularizado tem sido objeto de estudo para elucidar a diferenciação e o comportamento das células progenitoras. E mesmo com a utilização de diferentes tipos celulares como células de adenocarcinoma do pulmão, células de pulmão fetal, células endoteliais, células estaminais embrionárias, fibroblastos, célulastronco pluripotente induzidas, entre outras; apenas a recelularização parcial de alvéolos, vias aéreas e vasculatura pulmonar foi alcançada, por isso boa parte dos estudos vem acontecendo de forma limitada à traqueia ou a semeadura direta em fatias pulmonares. ${ }^{(60,61)}$

A utilização do biorreator dinâmico de vaso teve impacto na recelularização de pulmões descelularizados, mostrando vantagens no que se refere à crescimento celular e diferenciação quando comparada às condições estáticas. Porém questões como o método de descelularização ideal, a duração ideal para a recelularização completa do pulmão, os tipos celulares necessários, entre outros; demonstram que ainda não há como afirmar se essa técnica realmente melhora a eficiência da recelularização e da diferenciação de células-tronco de maneira segura. ${ }^{(60,61)}$

Estudos vêm sendo desenvolvidos com o objetivo de encontrar a melhor técnica de recelularização nos rins. Ross et al. foram os primeiros a relatar a recelularização em rim descelularizado de roedores com células-tronco embrionárias. $A$ 
perfusão ocorreu manualmente e se deu pela artéria renal e pelo ureter. ${ }^{(62)}$ Song et al. realizaram a infusão de células de rim de um rato neonatal através do ureter enquanto uma pressão negativa era exercida na câmara do órgão. Essa técnica conseguiu distribuir células por todo o compartimento glomerular, até o tufo glomerular. ${ }^{(63)}$

Ko et al. pré-trataram a matriz extracelular com o anticorpo CD31 para favorecer a adesão das células tubulares à parede vascular e desta forma melhorar a semeadura das células endoteliais ao longo da vasculatura renal. ${ }^{(64)}$ Caralt et al. realizaram a infusão do maior número de células epiteliais tubulares corticais renais humanas em um rim descelularizado de camundongo sob uma pressão maior do que a usava convencionalmente e obtiveram cobertura de até $50 \%$ em algumas partes do parênquima renal 24 horas após a semeadura. ${ }^{(65)}$

Este trabalho visa recelularizar um rim porcino descelularizado e observar a influência de componentes capazes de melhorar esse processo, como os exossomos, bem como observar como os fatores de crescimento, HGF e TGF- $\beta$, podem interferir positivamente ou negativamente no processo de recelularização. 


\section{MÉTODOS}

A metodologia empregada em todo o experimento foi constituída por três etapas: a obtenção de células renais humanas, a obtenção de exossomos oriundos das células-tronco mesenquimais e a descelularização do rim de porco. Os produtos de cada uma dessas etapas são os componentes fundamentais para a realização da etapa final: a recelularização do tecido renal (Figura 1). Desta forma, foi possível obter informações celulares suficientes para a avaliação da aderência celular em tecido anteriormente descelularizado.

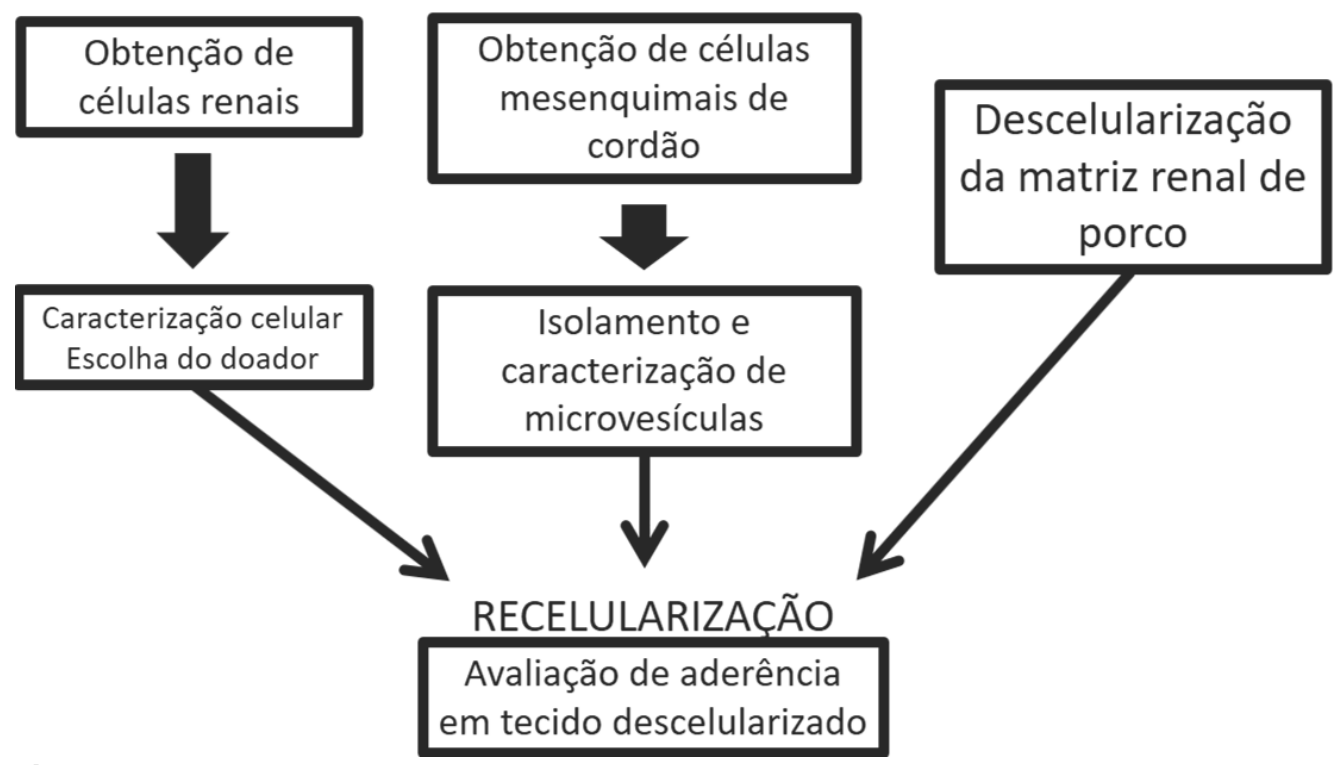

Figura 1. Esquema das etapas experimentais desenvolvidas

\subsection{Obtenção de células renais humanas}

Para obtenção de células renais, rins descartados de transplante renal por qualquer razão e livres de infecção viral (HIV, HCV ou HBV) foram enzimaticamente digeridos e a cultura primária de células iniciada. O tecido cortado e digerido enzimaticamente foi centrifugado, suspenso em meio de cultura suplementado e colocado em placas de cultura. A metodologia foi descrita em detalhe anteriormente. $^{(41)}$ 


\subsection{Caracterização de células renais humanas}

Para determinar quais os tipos celulares renais foram cultivados, utilizamos marcadores para células epiteliais tubulares proximais (neprilysin), células epiteliais tubulares distais (epithelial membrane antigen), ductos coletores (TammHorsfall protein), fibroblastos (CD73, S100A4 e Eritropoietina) e alpha-actina de músculo liso. A análise foi feita por citometria de fluxo (FACS). Além da caracterização de células renais, a presença de células progenitoras foi avaliada com citometria de fluxo utilizando-se dos marcadores CD133+, CD45+ e Oct4 para células progenitoras órgão específico. Células congeladas após este processo foram descongeladas e utilizadas neste projeto, porém essa metodologia foi estabelecida previamente em um projeto do mesmo grupo de pesquisa e os dados foram essenciais para o entendimento e construção deste atual projeto.

\subsection{Isolamento e caracterização de células mesenquimais de cordão e seus exossomos}

Células mesenquimais de cordão foram obtidas do banco de células do HIAE, sendo isoladas e caracterizadas de acordo com metodologia estabelecida abaixo.

\subsubsection{Isolamento e caracterização de células mesenquimais do cordão umbilical}

A veia do cordão umbilical foi lavada com o tampão fosfato salino (PBS - phosphate buffered saline) por 3 vezes, até eliminar todo o sangue. Após a lavagem, o cordão limpo foi transferido para placa de petri e cortado em pedaços de 2$5 \mathrm{~mm}^{3}$ com o auxílio do bisturi. Transferido para tubo Falcon com a solução enzimática de colagenase tipo I $(4 \mathrm{mg} / \mathrm{mL})$, pedaços do cordão foram imersos e incubados por 30 minutos à $37^{\circ} \mathrm{C}$.

Após a incubação, a solução foi filtrada em peneira granulométrica (abertura de 250 $\mathrm{m}$ / malha 60TY). Foi acrescentando 40mL de DMEM-LG + SBF 50\% (1:2) para diluir a solução e reduzir a viscosidade para coletar as células. Em seguida 
foi centrifugado à 1.200rpm (2x), temperatura ambiente, por 5 (cinco) minutos (sem break); descartado o sobrenadante e aliquotado em garrafas de cultura de $25 \mathrm{~cm} 2$ (T25) ou placa de cultura de 06 poços de $8,87 \mathrm{~cm}$.

Para o cultivo de células-tronco mesenquimais de cordão umbilical (CTM) foram usadas garrafas de cultura com a densidade de 4.000 células por $\mathrm{cm}^{2}$; e o meio de crescimento (DMEM-LG). A cada 48h foi dividido o conteúdo de uma garrafa em duas. Após atingir a confluência as células foram ressuspensas e contadas (Figura 2).

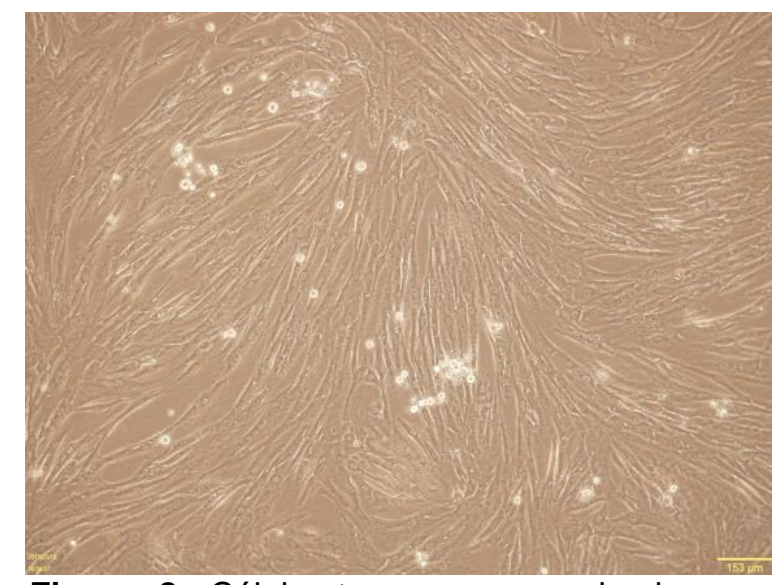

Figura 2. Células-tronco mesenquimais com confluência de $100 \%$

As células-tronco mesenquimais depois de isoladas, foram devidamente caracterizadas pelo método de citometria de fluxo realizada para confirmar a presença dos marcadores celulares CD29, CD44, CD73, CD90, CD166, e negativo para CD14, CD31, CD34, CD45, CD106, CD117 e CD133.

\subsubsection{Obtenção dos exossomos}

\subsubsection{Coleta do meio de cultura para extração dos exossomos}

Células mesenquimais de cordão umbilical ao atingirem 95\% de confluência foram lavadas com PBS e mantidas em cultura com meio sem soro. Após 24 horas foi avaliado se ocorreu morte celular. Caso negativo, células foram mantidas por mais 24 horas. Quando ocorreu morte celular de aproximadamente $20 \%$ das 
células em cultura, foi coletado o meio de cultura e transferido para tubos Falcon. $O$ meio coletado foi centrifugado.

As células sobreviventes foram mantidas mais $48 \mathrm{~h}$ em cultura com meio sem soro e novamente o meio de cultura foi coletado e centrifugado.

\subsubsection{Extração e purificação dos exossomos}

Para extração dos exossomos o meio coletado foi centrifugado duas vezes em diferentes velocidades, 300G por $10 \mathrm{~min}$ a $4^{\circ} \mathrm{C}$ para retirar as células; e $2000 \mathrm{G}$ por $10 \mathrm{~min}$ a $4^{\circ} \mathrm{C}$ para retirar as células mortas/debris.

Após centrifugação, o meio foi submetido a um ciclo de três ultracentrifugações. A primeira em $10000 \mathrm{~g}$ por $30 \mathrm{~min}$ a $4^{\circ}$ e o pellet será de microvesículas; a segunda ultracentrifugação em $100.000 \mathrm{G}$ por $120 \mathrm{~min}, 4^{\circ} \mathrm{C}$, o pellet estará constituído de exossomos e proteínas contaminantes; e a terceira ultracentrifugação à $100.000 \mathrm{G}$ por 120 minutos obtendo os exossomos no pellet.

As amostras de exossomos foram avaliadas por um analisador de nanopartículas (Nanosight).

\subsubsection{Identificação das proteínas em exossomos}

A identificação dos exossomos foi realizada através da técnica de western blot, sendo específicas para os marcadores de superfície CD63 e CD81.

\subsection{Descelularização de fragmentos de matriz renal de porco}

Para a obtenção de uma matriz acelular foi construído um sistema de descelularização de alto rendimento para que os resultados fossem reprodutíveis no futuro. Este biorreator customizado foi ligado através de cateteres na artéria e veia dos rins de porco e as mangueiras foram ligadas a dois galões de $20 \mathrm{~L}$, um para comportar as soluções de lavagem e outro para descarte dessas soluções (Figura 3). 


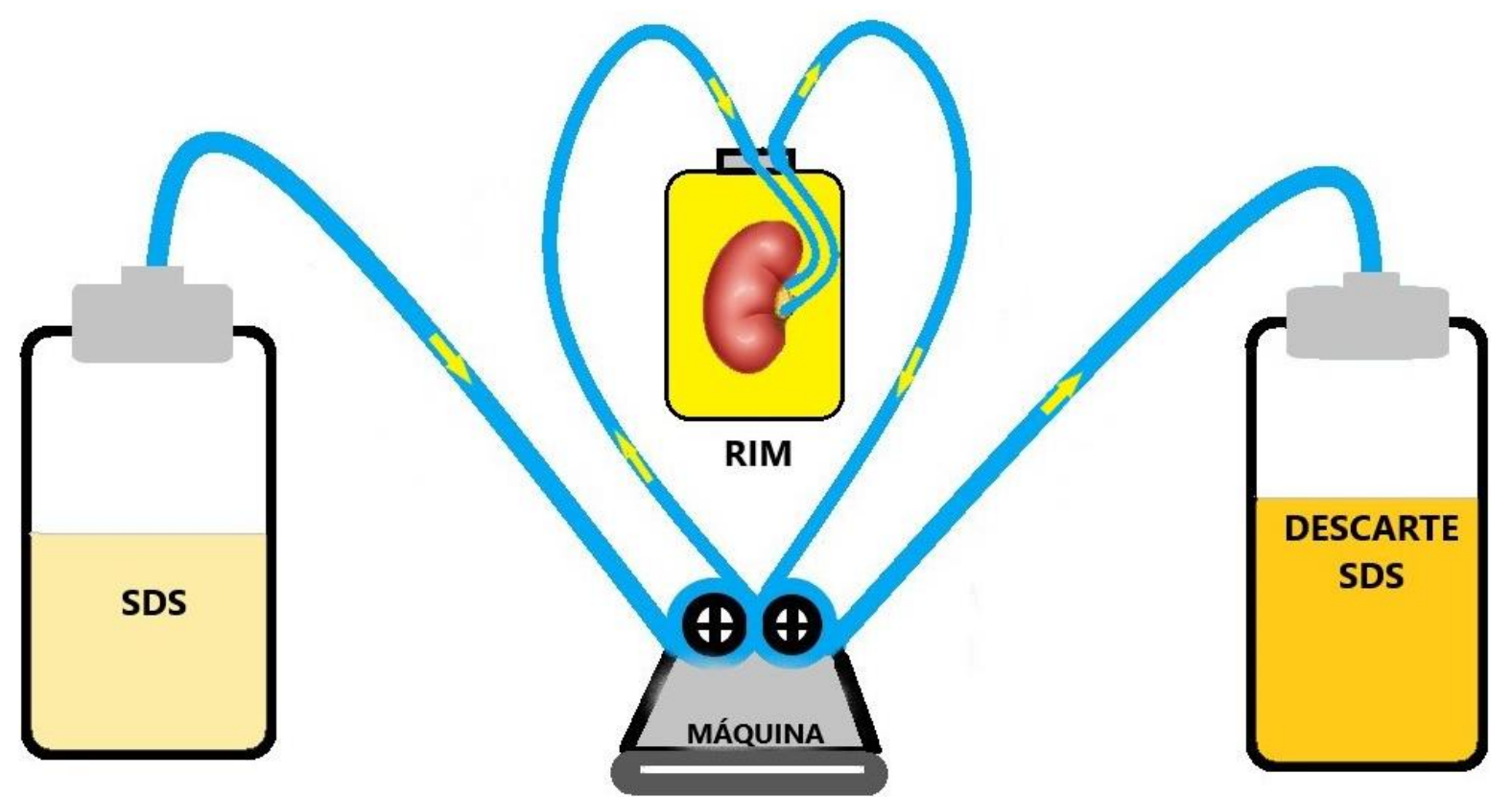

Figura 3. Esquema da dinâmica da descelularização no biorreator

Inicialmente um rim de porco foi descongelado à $-20^{\circ} \mathrm{C}$ por 24 horas e depois colocado à $4^{\circ} \mathrm{C}$ por 12 horas. Após esse período de descongelamento, o rim foi perfundido com solução salina por 5 minutos para verificar a viabilidade dos cateteres introduzidos na artéria e veia renal. A próxima etapa foi constituída por perfusão de solução do detergente aniônico SDS à 1\%, com perfusão continua durante 24 horas para promover a total remoção celular. $O$ órgão foi continuamente observado para acompanhar o clareamento que indicou a distribuição uniforme da perfusão confirmando o processo de descelularização. Concluído o período de descelularização com SDS, o rim suíno foi reperfundido com água milli-Q por mais 24 horas até que o desaparecimento da espuma indicasse a total remoção do detergente.

O rim foi reperfundido utilizando PBS por mais 3 horas para lavar as estruturas vasculares do órgão. Após a finalização da perfusão com PBS, os rins foram colocados em formol $10 \%$ e encaminhados para histologia.

\subsection{Avaliação de aderência em tecido descelularizado}

Células humanas renais de cultura primária foram incubadas com meio específico em placas junto à fragmentos de matriz descelularizada em diferentes concentrações de fatores de crescimento HGF e TGF- $\beta$, na presença e ausência de 
exossomos. Estes fatores foram escolhidos por terem sido descritos na literatura como envolvidos no processo de regeneração renal em modelo animal (Figura 4).
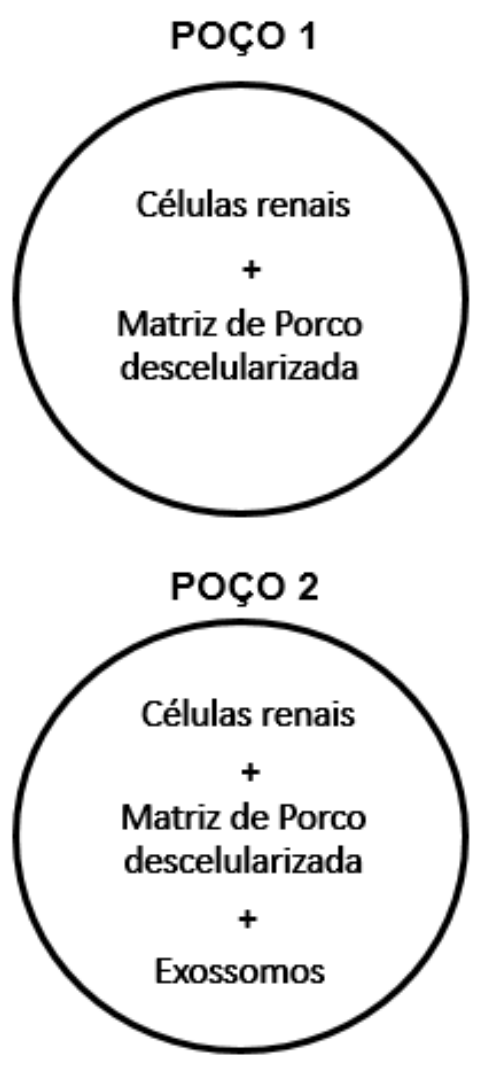

POÇO 3

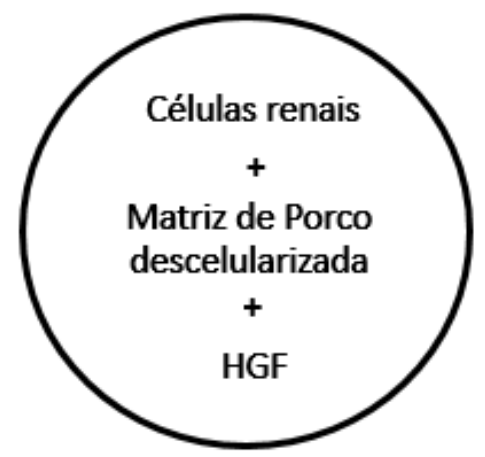

POÇO 4

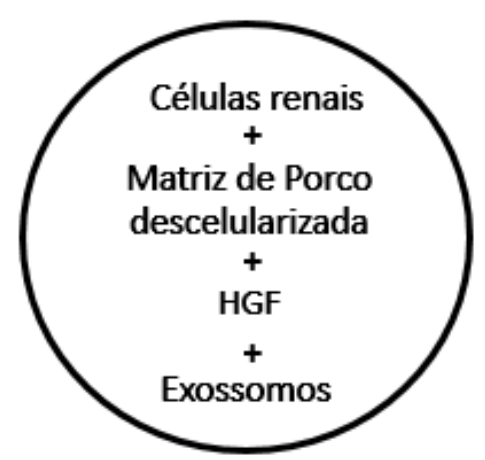

POÇO 5

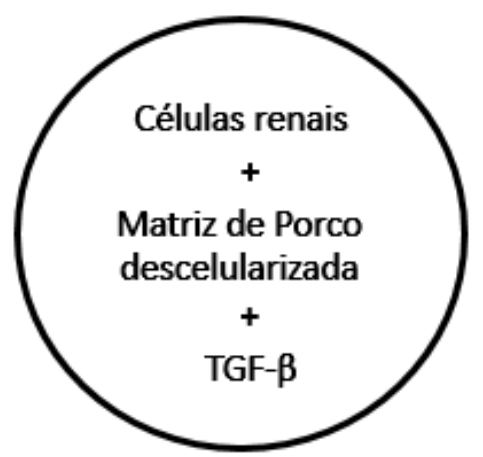

POÇO 6

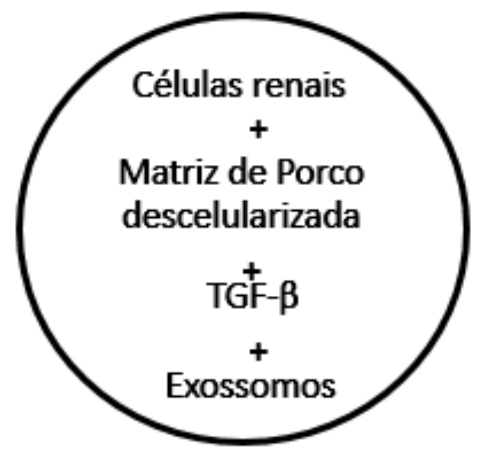

Figura 4. Estratégias de experimento para regeneração renal

O experimento de recelularização foi realizado em triplicata e repetido também em triplicata. Em cada poço do experimento foi inserido: $10^{5}$ células renais humanas e um fragmento de $5 \mathrm{~mm}$ de matriz descelularizada. $O$ exossomos inseridos no experimento foram extraídos de $10^{5}$ células mesenquimais de cordão umbilical mantendo assim a proporção celular. Nos poços tratados com HGF (SigmaAldrich) a concentração foi de $20 \mathrm{ng} / \mathrm{mL}(160 \mu \mathrm{L})$, e o TGF- $\beta$ (R\&D Systems) na concentração de 5-10ng/mL (100 $\mu \mathrm{L})$.

Os tecidos foram fixados para análise após nove dias em cultura em incubadora. Os tecidos fixados foram cortados em micrótomo em $5 \mu \mathrm{m}$ e corados com coloração por hematoxilina-eosina (H\&E). Imuno-histoquímica com caspase 3 (Invitrogen) foi realizada para avaliar morte celular. A amostra passou pelo processo de desparafinização, seguida da adição de solução tampão do Kit Dako na proporção 2 $\mathrm{mL} / 100 \mathrm{~mL}$ de água destilada e exposta à aquecimento por $12 \mathrm{~min}$. Foi lavado com a solução de lavagem tampão (DAKO) 3x por 5 minutos e foi adicionada solução de 
bloqueio da peroxidase em solução de $\mathrm{H}_{2} \mathrm{O}_{2} 6 \%$. Repete-se a operação de lavagem e foi adicionado Protein Block (DAKO) por 30 minutos. Após nova lavagem, as lâminas foram incubadas com o anticorpo anticaspase 3 overnight em uma câmara úmida na geladeira. Depois desta etapa, foi lavado novamente e incubado com o anticorpo secundário (DAKO) por 90 minutos. Lavou-se novamente e foi adicionado por 1 minuto o cromógeno DAB que promoveu a reação. Em seguida as laminas foram lavadas e colocadas na água por 10 segundos. O material então foi mergulhado em hematoxilina por 1 minuto, foi lavado duas vezes com água destilada por 10 segundos e então em protocolo estabelecido, o processo de diafinização foi feito para fixar e preparar o material para análise por microscopia.

\subsection{Aspectos éticos}

Estudo foi realizado após aprovação do Sistema Gerenciador de Projetos de Pesquisa (2618-16) e aprovado na Plataforma Brasil CAAE: 57565316.9.000.0071. 
4 RESULTADOS

\subsection{Obtenção e caracterização das células renais humanas}

\subsubsection{Células renais humanas}

Para obtenção das células renais humanas, rins descartados do transplante renal e doados para pesquisa tiveram seus fragmentos digeridos enzimaticamente e culturas de células renais humanas foram iniciadas, expandidas e caracterizadas.

Foram coletados tecidos renais de 20 doadores, dos quais 12 foram caracterizadas por citometria de fluxo. As demais culturas foram descartadas por não apresentarem crescimento satisfatório. Para caracterização utilizamos os seguintes anticorpos e seus fluorocromos estabelecidos na tabela 1.

Tabela 1. Distribuição dos anticorpos e fluorocromos para os ensaios de citometria

\begin{tabular}{lcc}
\hline Anticorpos & Células & Fluorocromo \\
\hline THP & Ducto coletor & Alexa Fluor 488 (Rabbit) \\
EMA & Túbulo distal & APC (Mouse) \\
EPO & Fibroblasto produtor de eritropoietina & Alexa Fluor 488 (Rabbit) \\
NEP & Túbulo proximal & Alexa Fluor 488 (Rabbit) \\
CD73 & Fibroblasto & APC (Mouse) \\
\hline THP: Tamm-Horsfall protein; EMA: epithelial membrane & antigen; EPO: erythropoietin; NEP: \\
neprilysin; CD73: cluster of differentiation 73. &
\end{tabular}

Com uso destes anticorpos foi possível avaliar a existências de células de túbulo proximal, distal, ducto coletor bem como fibroblastos produtores de eritropoietina. Na tabela 2 demonstramos as medidas de luminescência das células em relação a cada anticorpo.

Com o objetivo de ver a sensibilidade do método empregado e sua especificidade, as células foram duplamente marcadas, assim pudemos comprovar que as células apenas eram positivas para um marcador. Na tabela 2 estão em negrito os tipos celulares específicos. 
Tabela 2. Medidas de citometria

\begin{tabular}{|c|c|c|}
\hline $\begin{array}{c}\text { Medidas de fluorescência pela citometria } \\
(\%)\end{array}$ & $\begin{array}{c}\text { Mediana } \\
\text { (1 e } 3 \text { quartis) }\end{array}$ & Mínimo e máximo \\
\hline Unstained (control) & $99.80(99.65-99.90)$ & $99.50 ; 100.00$ \\
\hline EMA + THP (LL) - duplo negativo & $94.55(78.25-98.40)$ & $62.60 ; 99.30$ \\
\hline EMA + THP (LR) - duplo positivo & $0.00(0.00-0.05)$ & $0.00 ; 0.60$ \\
\hline EMA + THP (UL) - positivo apenas para EMA & $5.10(1.10-21.30)$ & $0.40 ; 36.90$ \\
\hline EMA + THP (UR) - positivo apenas para THP & $0.30(0.20-0.45)$ & $0.10 ; 0.60$ \\
\hline EMA + THP (LR) - duplo positivo & $5.40(1.65-21.65)$ & $0.80 ; 37.50$ \\
\hline EPO + Oct4 (LL) - duplo negativo & $6.60(1.00-27.35)$ & $0.70 ; 58.90$ \\
\hline EPO + Oct4 (LR) - duplo positivo & $0.00(0.00-0.00)$ & $0.00 ; 0.10$ \\
\hline EPO + Oct4 (UL) - positivo apenas para EPO & $89.55(69.05-91.90)$ & $40.80 ; 95.30$ \\
\hline EPO + Oct4 (UR) - positivo apenas para Oct4 & $4.25(2.15-5.80)$ & $0.30 ; 9.50$ \\
\hline EPO + Oct4 (LR) - duplo positivo & $93.35(72.60-99.05)$ & $41.10 ; 99.30$ \\
\hline CD24+ CD44 (LL) - duplo negativo & $81.30(63.60-98.90)$ & $16.30 ; 99.50$ \\
\hline CD24+ CD44 (LR) - duplo positivo & $0.05(0.00-0.10)$ & $0.00 ; 0.50$ \\
\hline CD24+ CD44 (UL) - positivo apenas CD24 & $18.25(0.55-35.95)$ & $0.20 ; 83.20$ \\
\hline CD24+ CD44 (UR) - positivo apenas CD44 & $0.40(0.20-0.40)$ & $0.00 ; 0.50$ \\
\hline CD24+ CD44 (LR) - duplo positivo & $18.70(1.05-36.30)$ & $0.50 ; 83.70$ \\
\hline $\mathrm{NEP}+\mathrm{CD} 73(\mathrm{LL})-$ duplo negativo & $99.25(98.50-99.40)$ & $73.20 ; 99.50$ \\
\hline NEP + CD73 (LR) - duplo positivo & $0.10(0.05-0.20)$ & $0.00 ; 0.50$ \\
\hline NEP + CD73 (UL) - positivo apenas para NEP & $0.40(0.30-0.95)$ & $0.20 ; 26.30$ \\
\hline $\begin{array}{l}\text { NEP + CD73 (UR) - positivo apenas para } \\
\text { CD73 }\end{array}$ & $0.30(0.10-0.35)$ & $0.10 ; 0.60$ \\
\hline NEP + CD73 (LR) - duplo positivo & $0.80(0.60-1.50)$ & $0.50 ; 26.70$ \\
\hline
\end{tabular}

Congelamos células destes 12 doadores para continuar experimentos.

\subsection{Isolamento e caracterização de células mesenquimais de cordão e obtenção de microvesículas e exossomos}

As células mesenquimais de cordão umbilical humano foram isoladas, cultivadas e replicadas até passagens cinco e 10 conforme protocolo.

A produção dos exossomos, microvesículas foi estimulada, em células mesenquimais de cordão umbilical, através de privação de fatores de crescimento. As células em confluência de $80 \%$ foram mantidas com meio de cultura pobre em glicose e sem suplementos por $24 \mathrm{~h}$ coletado o meio, as células recebiam 
novamente meio de cultura pobre em glicose e sem suplementos esse procedimento foi repetido a cada $24 \mathrm{~h}$ até que $80 \%$ das células morressem.

\subsubsection{Obtenção de microvesículas e exossomos}

O meio de cultura coletado foi submetido às etapas de centrifugações e ultracentrifugações para isolamento das microvesículas e exossomos. A leitura em Nanosight (Tabela 3, Figura 5) comprovou a presença de microvesículas e a medida oferecida pelo Nanosight demonstra que estamos diante de exossomos (média de 120nm de tamanho).

Tabela 3. Média do tamanho das microvesículas extraídas de 100.000 células mesenquimais

\begin{tabular}{lcc}
\hline Experimentos & $\begin{array}{c}\text { Média tamanho } \\
(\mathbf{n m})\end{array}$ & $\begin{array}{c}\text { Concentração de partículas } \\
(\mathbf{m L})\end{array}$ \\
\hline Experimento 1 & 119,2 & $4,87+008 \pm 1,21+007$ \\
Experimento 2 & 118,9 & $7,06+008 \pm 3,16+007$ \\
Experimento 3 & 117,6 & $7,62+007 \pm 5,05+006$ \\
Experimento 4 & 125,2 & $4,64+008 \pm 4,96+007$ \\
\hline
\end{tabular}
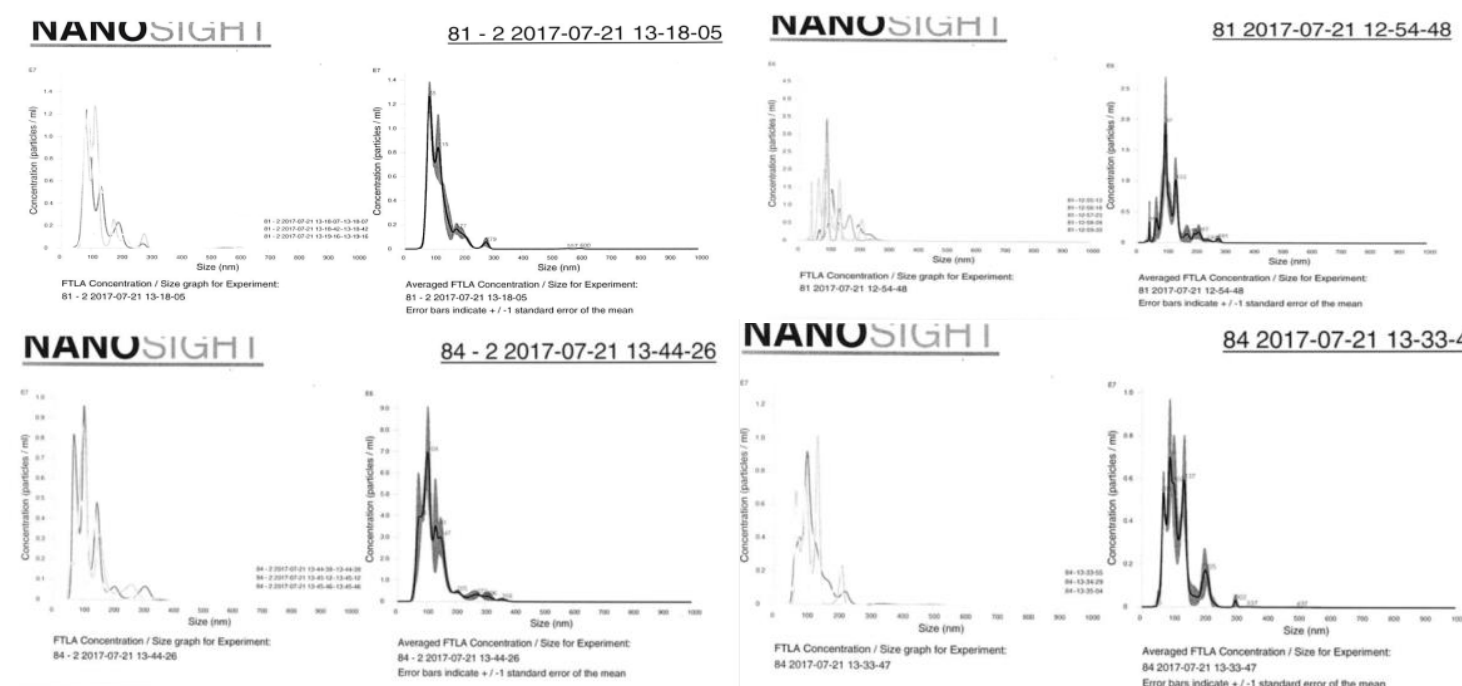

NANUSIGIHI

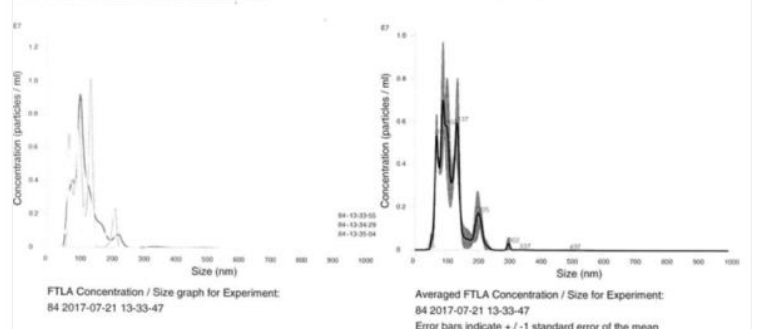

Figura 5. Gráficos ilustrativos dos experimentos de caracterização de exossomos

A análise pelo aparelho Nanosight permite a visualização destas nanopartículas através de um modo de fluorescência que segue na figura 6 . 


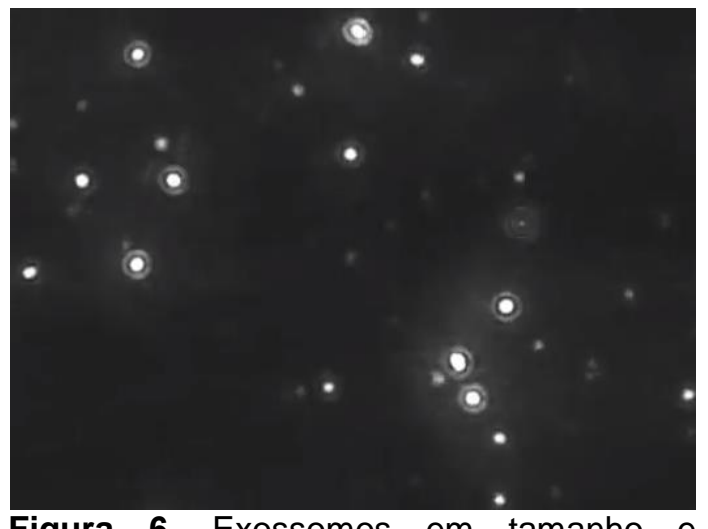

Figura 6. Exossomos em tamanho e dimensões diferentes encontrados pela análise no Nanosight

Frente à presença de vesículas de tamanho inferior a 120nm, realizamos também o western blot para os marcadores de superfície CD63 e CD81 que caracterizam as vesículas como exossomos de células mesenquimais (Figura 7).

\section{Amostra 1 Amostra 2}

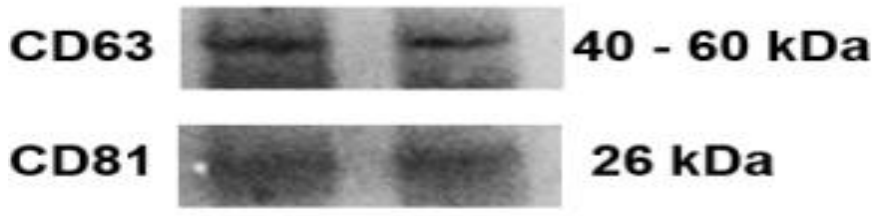

Figura 7. Western blot para CD63 e CD81 em exossomos produzidos por células mesenquimais de cordão

As vesículas de tamanho inferior a 120nm e positivas para CD63 e

CD81 foram denominadas exossomos e congeladas para 0 experimento de recelularização.

\subsection{Descelularização}

O processo de descelularização foi realizado com biorreator customizado. O biorreator foi construído seguindo os padrões impostos pela literatura para a melhor execução das atividades de descelularização conforme demonstrado na figura 8. 


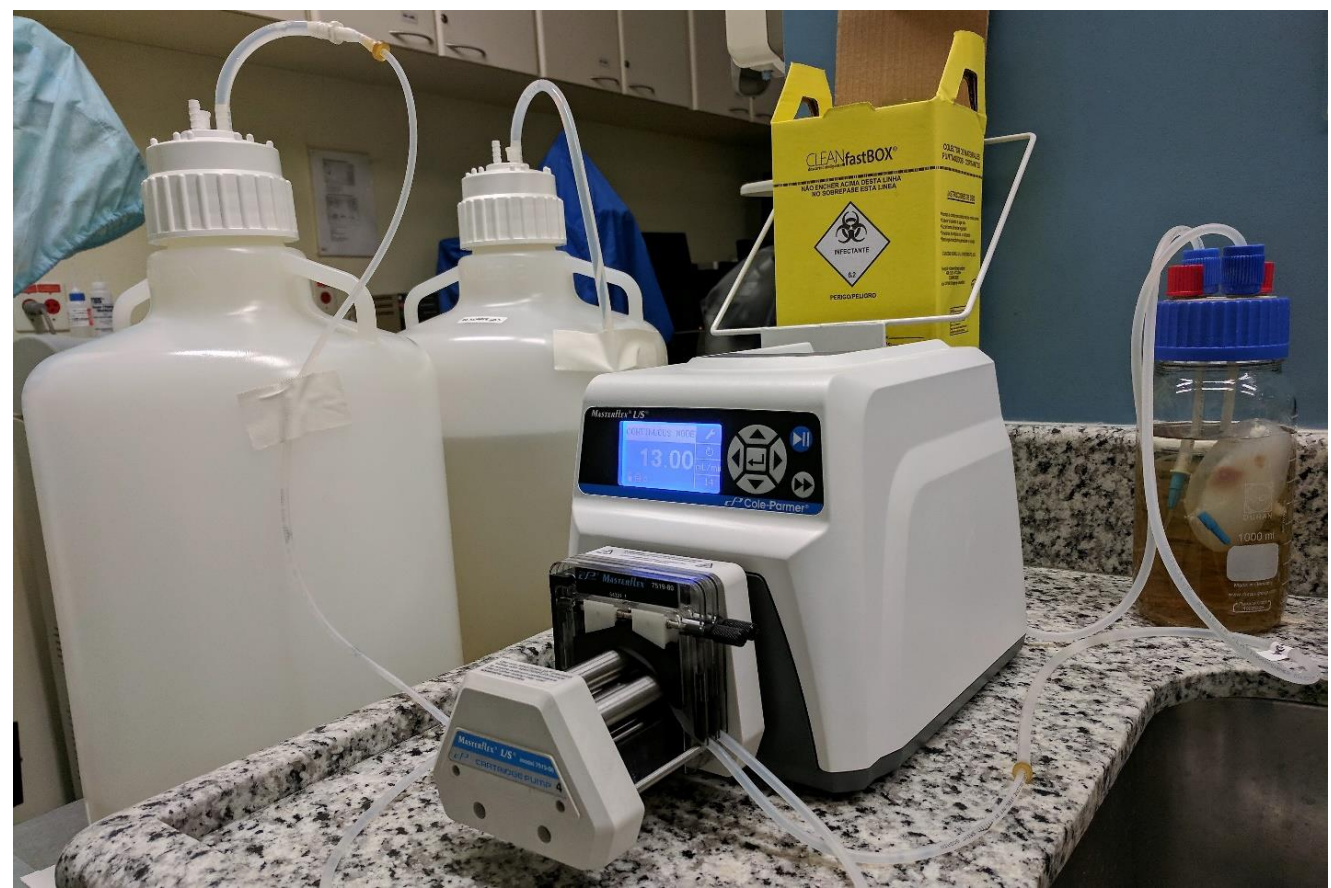

Figura 8. Biorreator customizado em atividade

O biorreator trabalhou de forma dinâmica e ininterrupta para que não houvessem falhas durante qualquer momento do processo de descelularização. Os resultados demonstraram perfusão do SDS em todo tecido, confirmado pela sua coloração esbranquiçada no final da atividade do biorreator como visto nas figuras a seguir.

Os resultados da etapa de descelularização estão ilustrados na figura 9. O rim porcino durante o tempo de perfusão por SDS exibiu clareamento, o que sugere a distribuição de forma uniforme do processo de perfusão, confirmando que o método de descelularização aconteceu de forma dinâmica e eficiente. 


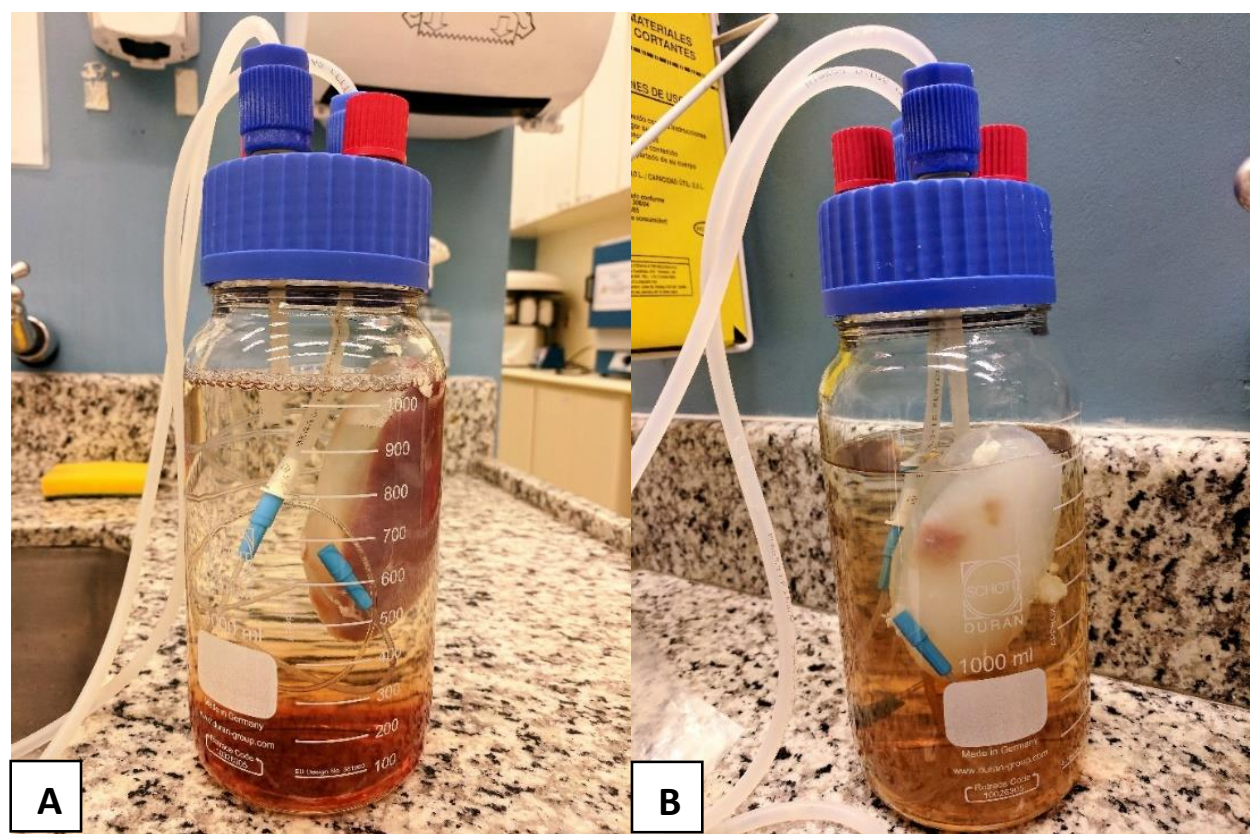

Figura 9. Do lado esquerdo (A), o rim em processo de descelularização; e do lado direito (B), o rim completamente descelularizado

Para comprovar o resultado microscópico da descelularização, fragmentos de tecido matricial foram fixados e submetidos a análise histológica do tecido. A histologia com coloração por H\&E demonstrou a ausência de células na matriz (ausência de coloração com hematoxilina) e a ausência de núcleos celulares pela ausência de eosina (Figuras 10 e 11). A histologia com H\&E exibiu também a conservação na integridade do endotélio do vaso sanguíneo do material descelularizado (Figura 10).

Outro resultado visualizado por histologia está representado na figura 11, que exibe estruturas de parênquima renal com conformação de glomérulos. 


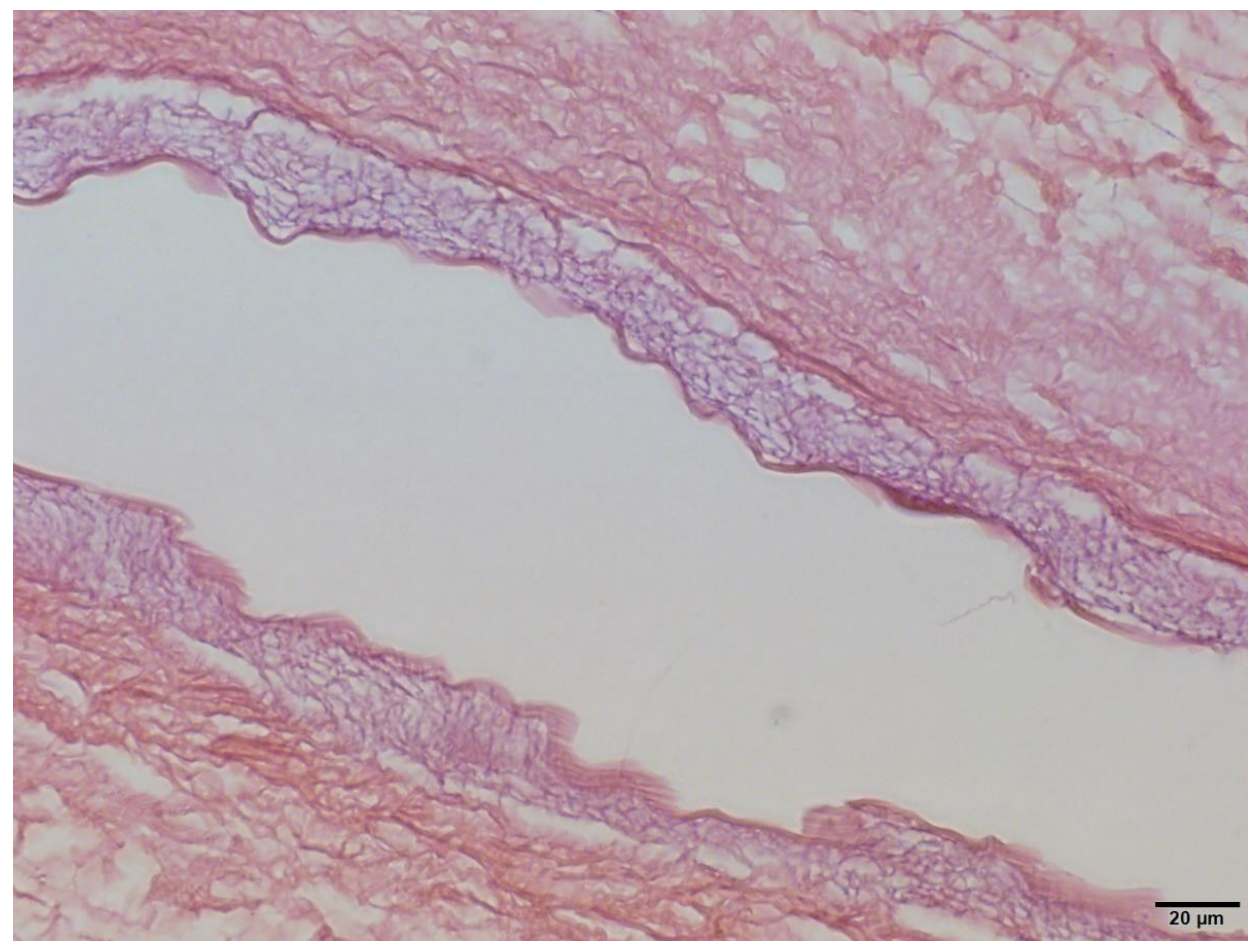

Figura 10. Tecido descelularizado do rim do porco com estrutura vascular preservada com camadas bem definidas

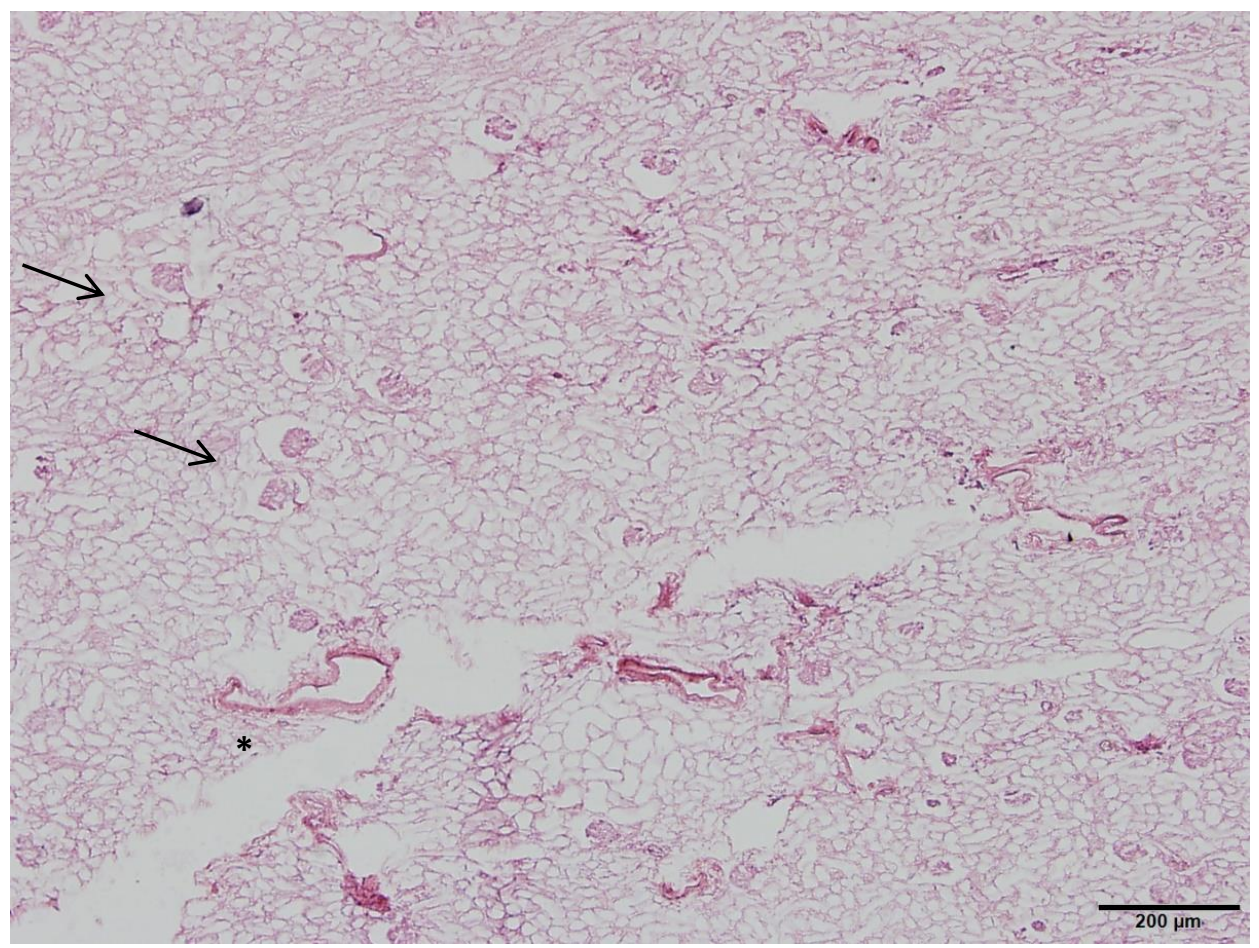

Setas indicam imagens sugestivas de glomérulos. * marca vaso conservado no processo de descelularização.

Figura 11. Tecido descelularizado do rim do porco 


\subsection{Recelularização}

A recelularização foi o objetivo principal deste estudo. Nesta etapa todos os componentes foram associados com a finalidade de recelularizar a matriz porcina descelularizada.

A tabela 4 apresenta os números de células renais humanas inseridas em cada poço da placa de cultura junto com a matriz porcina descelularizada. Após sete dias, o número de células que aderiram à placa de cultura foi avaliado para inferir a possível migração destas células para a matriz descelularizada e uma possível multiplicação celular.

Tabela 4. Comparação da quantidade de células inicial e final no processo de recelularização

\begin{tabular}{ccc} 
& № de células experimento I & № de células experimento II \\
\hline Início & $1 \times 10^{5}$ & $1 \times 10^{5}$ \\
Final & $1,2 \times 10^{4}$ & $9,4 \times 10^{4}$ \\
\hline
\end{tabular}

Em ambos os experimentos 100.000 células renais humanas foram inseridas em cada um dos seis poços da placa de cultura. No primeiro experimento 12.000 aderiram à placa, o que corresponde a $12 \%$ das células iniciais. $O$ segundo experimento foi realizado com a mesma quantidade inicial de células, e dessas, 94.000 células se aderiram à placa, ou seja, $94 \%$ do total inserido.

Após nove dias em cultura os fragmentos de matriz foram fixados para realizar as análises histológicas e imuno-histoquímicas.

A recelularização foi realizada em dois experimentos independentes e em triplicata. O Grupo 1 (G1) foi o ensaio em que as células renais humanas e a matriz foram associadas e serviu como grupo controle. $\mathrm{Na}$ análise histológica em ambos os experimentos observou-se a presença de células aderidas à região mais externa da matriz (Figura 12). 


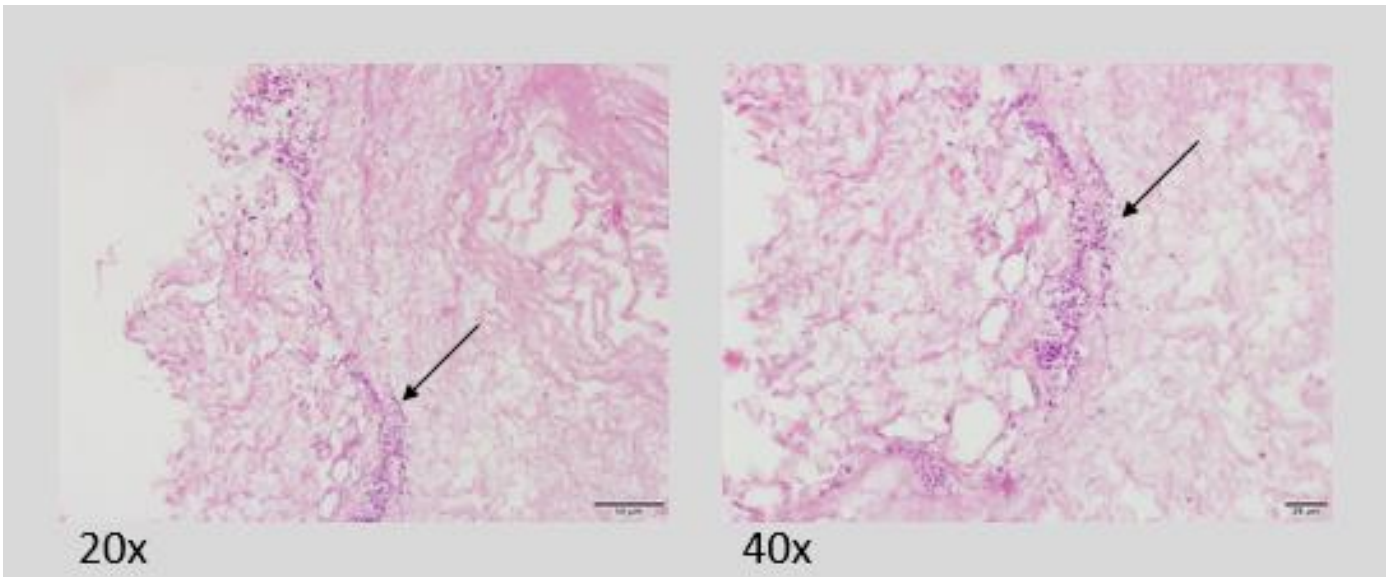

Figura 12. Grupo 1 - Células renais humanas em matriz descelularizada após 9 dias em cultura

$\mathrm{Na}$ presença de exossomos, as células renais humanas aderiram nas estruturas descelularizadas, como vasos e glomérulos, exibindo uma capacidade de migração ao interior desta matriz (Figura 13).

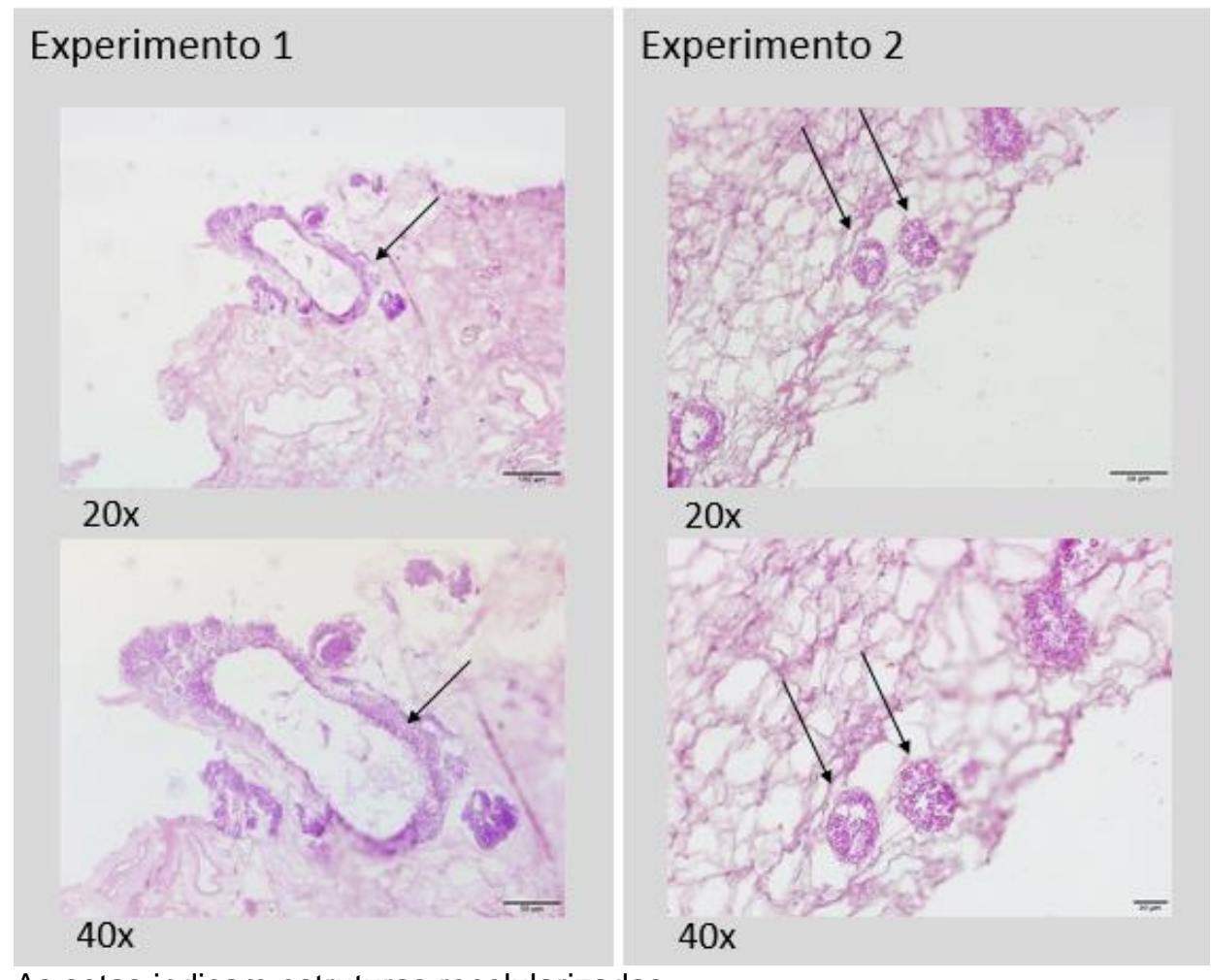

As setas indicam estruturas recelularizadas.

Figura 13. Grupo 2 - Exossomos inseridos junto à matriz descelularizada e as células renais

O terceiro grupo estudado (G3) avaliou a inserção de fator de crescimento de hepatócito (HGF) descrito na literatura como fator de crescimento de 
células renais. Na presença de HGF houve células no tecido também aderindo às estruturas na figura 14.

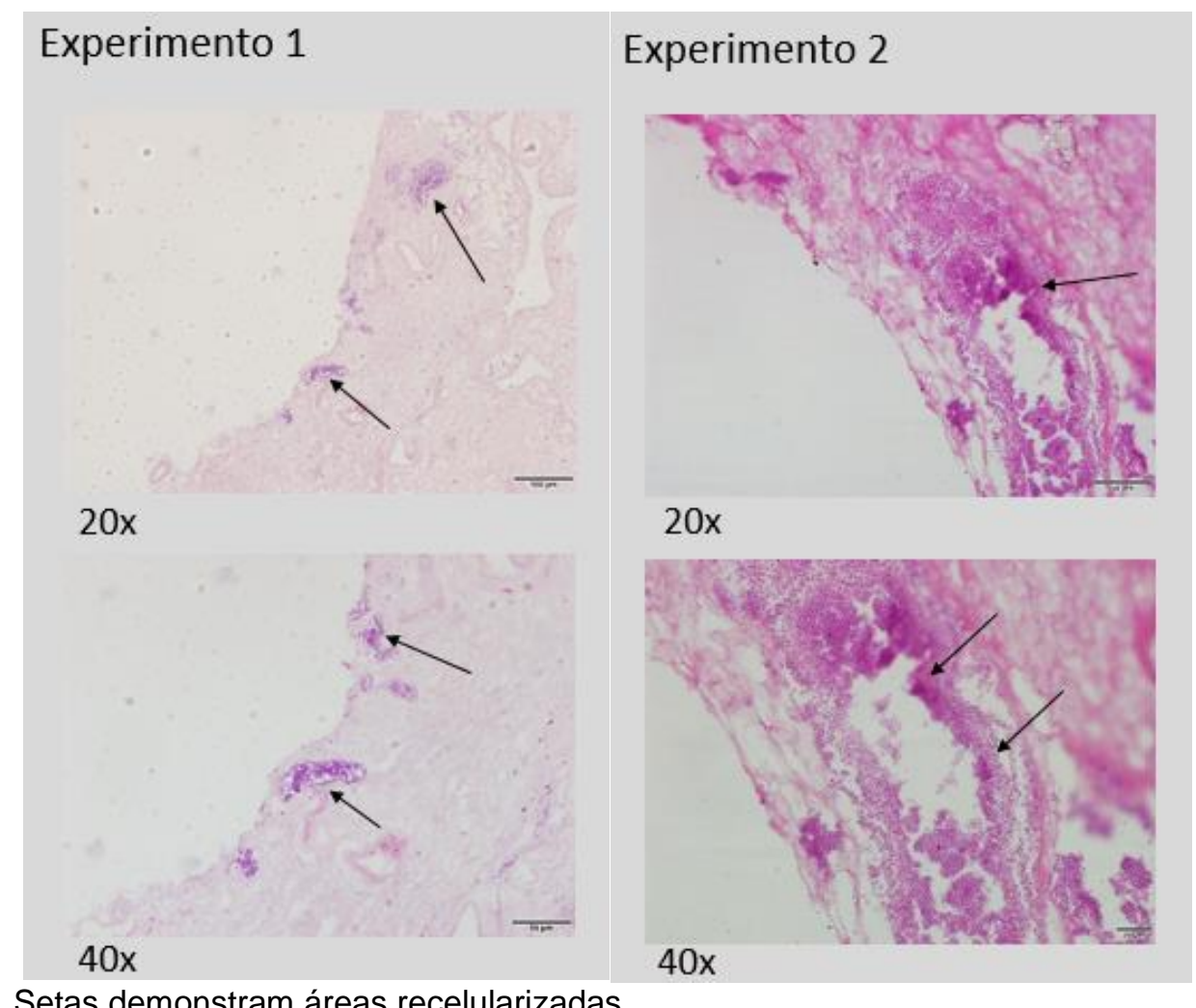

Setas demonstram áreas recelularizadas.

Figura 14. Grupo 3 - Fator de crescimento de hepatócitos com células e matriz

No Grupo 4 (G4), adicionamos os exossomos e o HGF para avaliar um possível efeito sinérgico dos exossomos e HGF. Essa associação determinou resultados dependentes do doador celular. Em um experimento observaram-se conglomerados de células na periferia da matriz enquanto no segundo grupo de triplicatas não houve crescimento celular (Figura 15). 


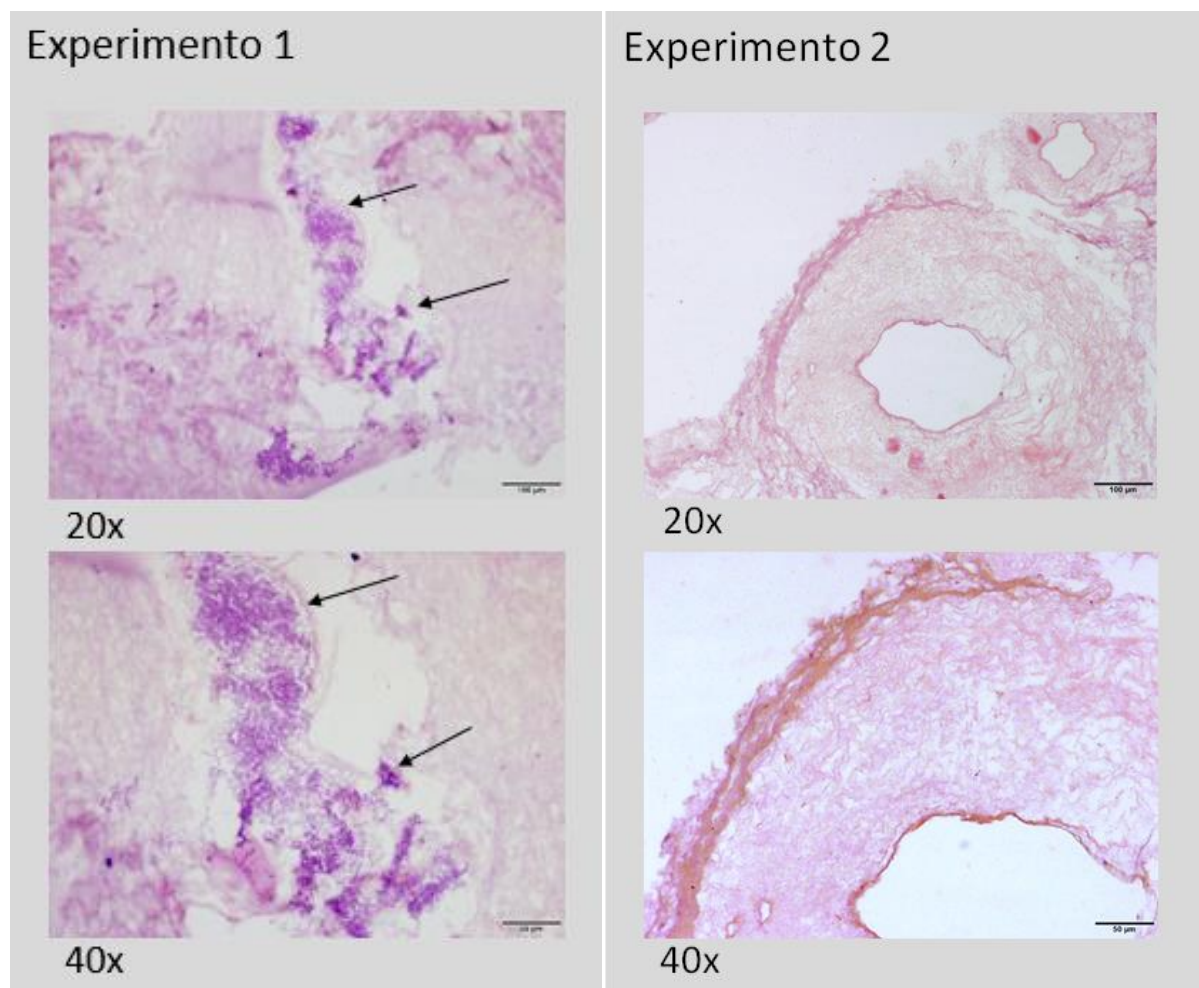

Figura 15. Grupo 4 - Associação de exossomos e fator de crescimento de hepatócitos à matriz e células renais

O quinto grupo estudado (G5) avaliou o uso de TGF- $\beta$, um conhecido fator pró-fibrótico renal, e houve discreto crescimento celular na matriz (Figura 16).

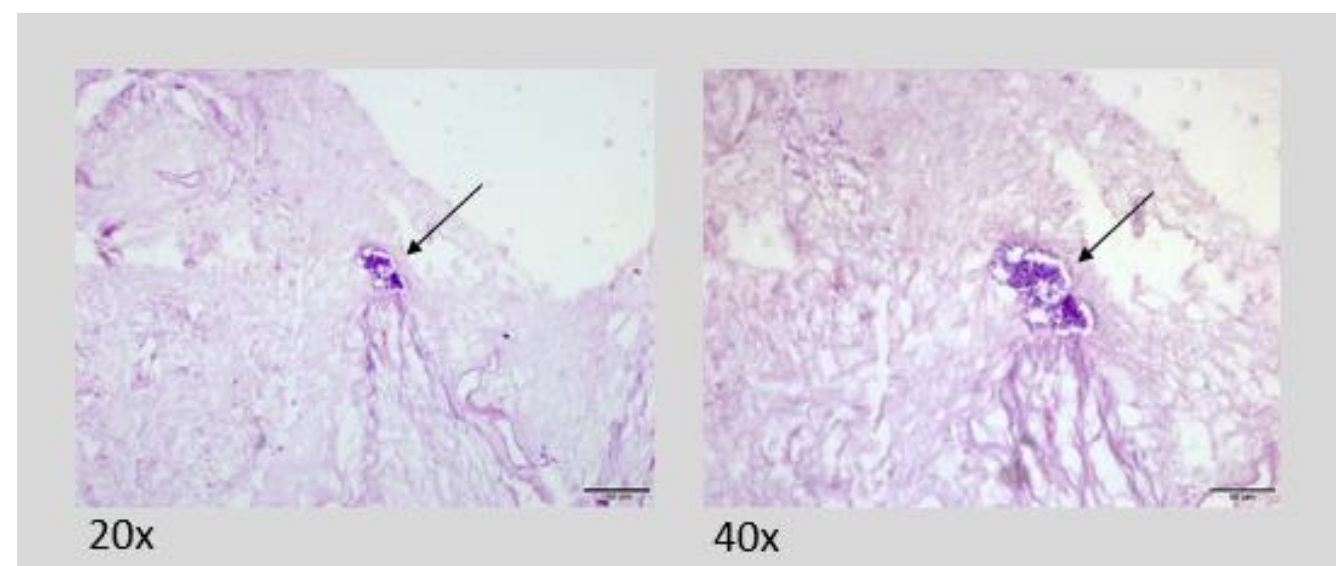

Figura 16. Grupo 5 - Fator de crescimento transformador beta em cultura de células renais e matriz

Quando avaliamos a associação de exossomos e fator de crescimento sintético, no caso TGF- $\beta$ (G6), os resultados foram irregulares. No primeiro 
experimento houve crescimento celular, enquanto que no segundo experimento não houve crescimento celular (Figura 17).

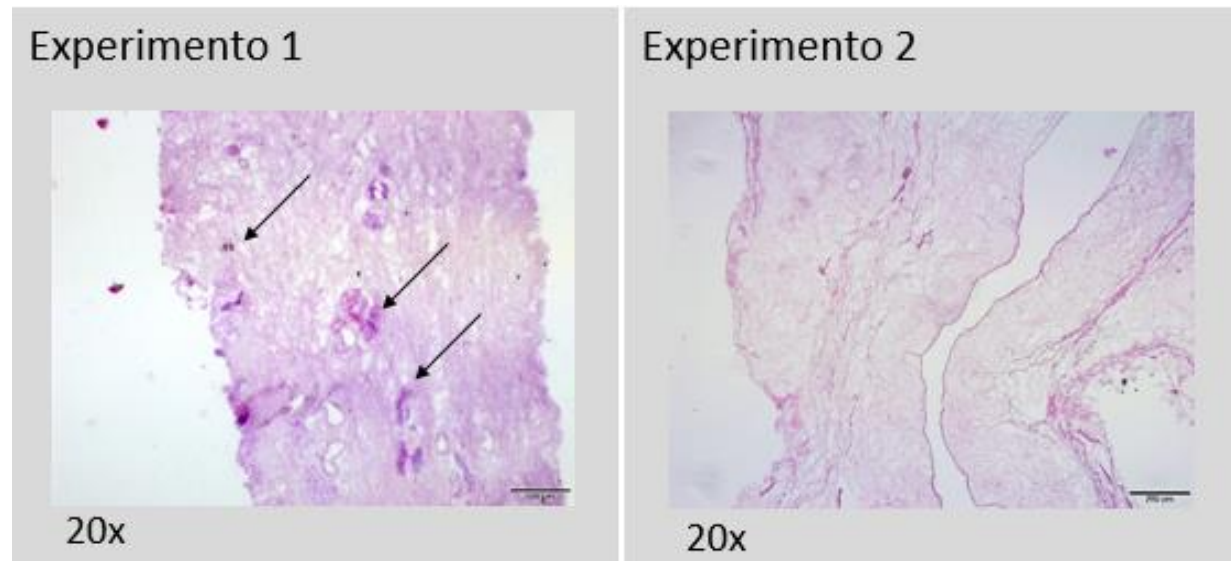

Figura 17. Grupo 6 - Exossomos e fator de crescimento transformador beta em cultura de células renais e matriz

A recelularização da matriz com células humanas renais ocorreu em quase todos os experimentos, o que foi comprovado histologicamente. Para avaliar a viabilidade de uma recelularização efetiva, observamos a morte celular com imunohistoquímica utilizando a caspase 3 . O interior celular fica corado em marrom quando há morte das células.

No Grupo G1 quando células renais foram associadas apenas à matriz observou-se grande quantidade de células apoptóticas (Figura 18).

A presença de exossomos determinou menor positividade para caspase 3 , ou seja, das células que migraram na matriz não existiam muitas células apoptóticas (Figura 19).

O Grupo G3, na presença do HGF, observou-se uma pequena quantidade de células que foram positivas para caspase 3 , demonstrando, portanto, morte celular (Figura 20).

No Grupo G4, exossomos juntamente com HGF, não foi verificado nenhuma célula em tom amarronzado (Figura 21).

Nos ensaios que foram utilizados o fator pró-fibrótico TGF- $\beta$, não foi visto morte celular (Figura 22), no entanto, quando associado o fator TGF- $\beta$ aos exossomos, observou-se um elevado número de células apoptóticas, entretanto este resultado não se repetiu (Figura 23). 
G1

Experimento 1

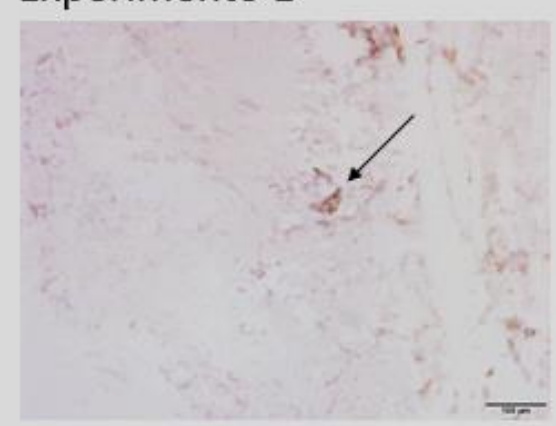

Experimento 2

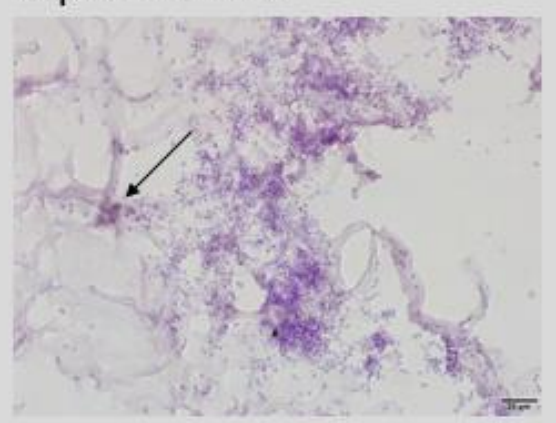

Figura 18. Grupo 1 - Morte de células renais humanas evidenciada em matriz recelularizada

\section{G2}

\section{Experimento 1}

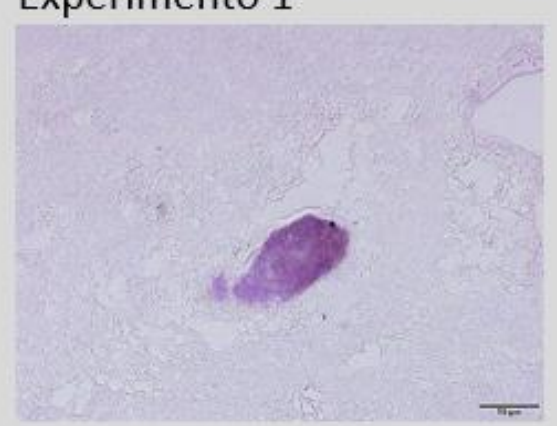

\section{Experimento 2}

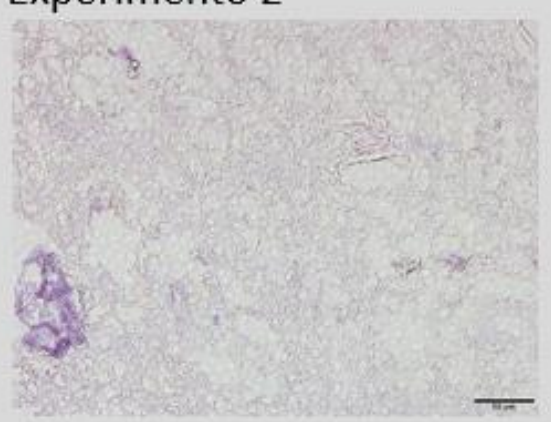

Figura 19. Grupo 2 - Matriz recelularizada com menor taxa de morte celular

G3

Experimento 1

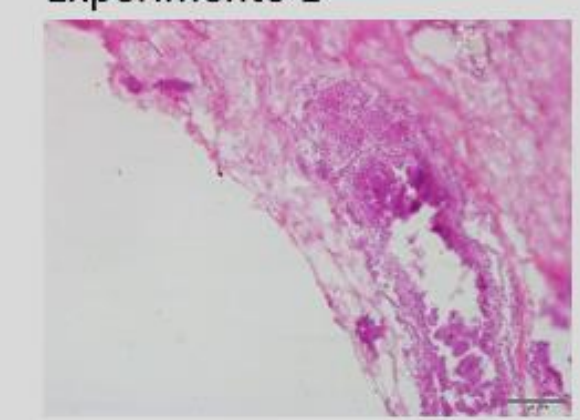

\section{Experimento 2}

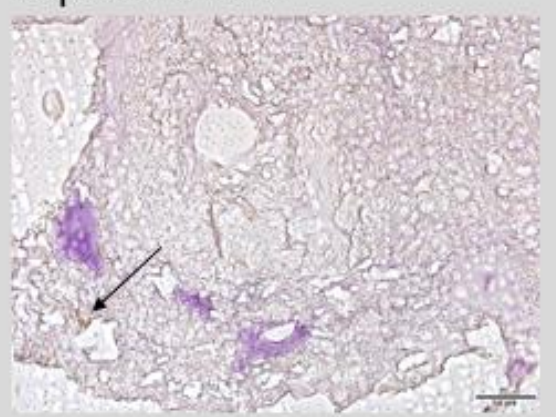

Figura 20. Grupo 3 - Pequena quantidade de células apoptóticas com o fator de crescimento de hepatócitos inserido no meio 


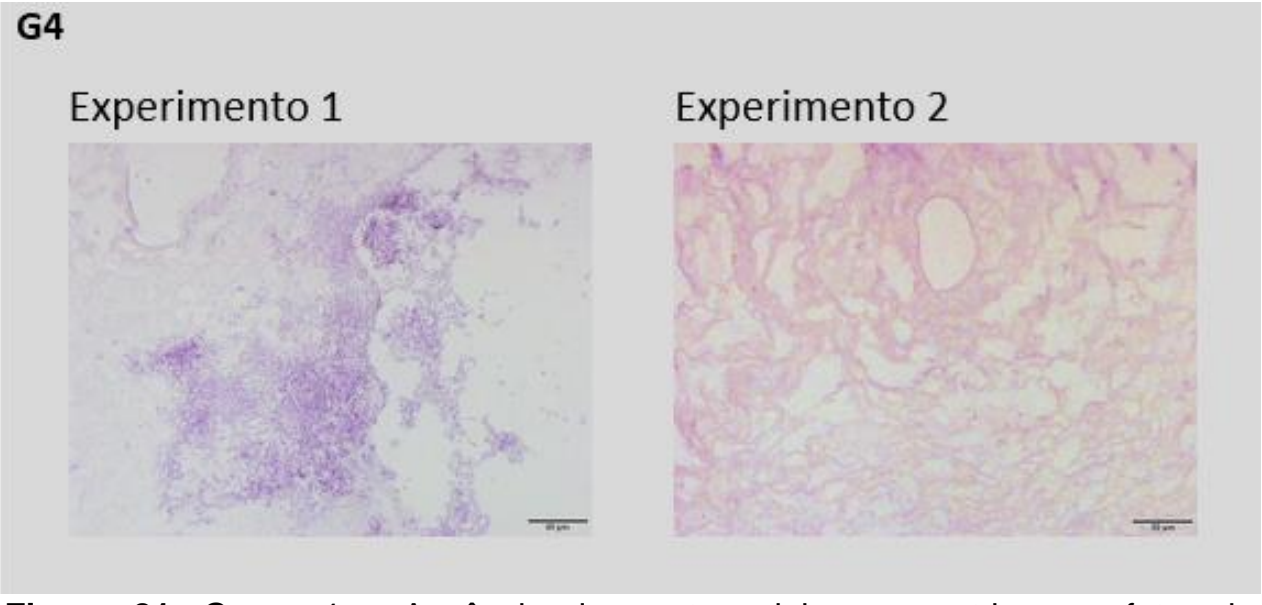

Figura 21. Grupo 4 - Ausência de morte celular na matriz com fator de crescimento de hepatócitos e exossomos

G5

\section{Experimento 1}

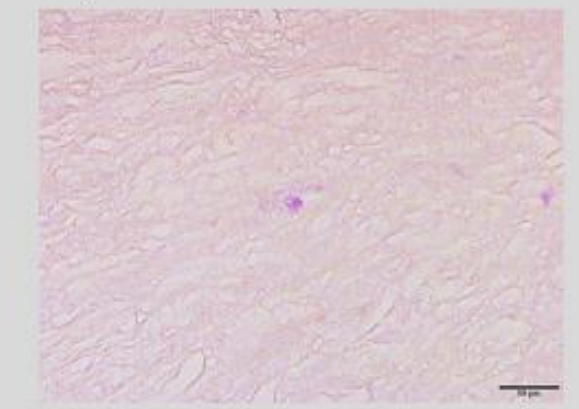

\section{Experimento 2}

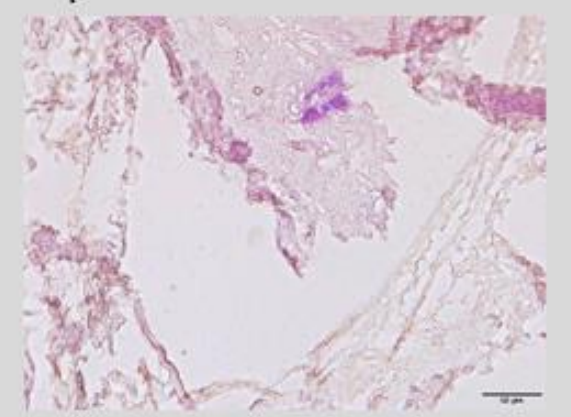

Figura 22. Grupo 5 - Pouca recelularização e nenhuma célula em processo de apoptose sob a influência de fator de crescimento transformador beta

\section{G6}

Experimento 1

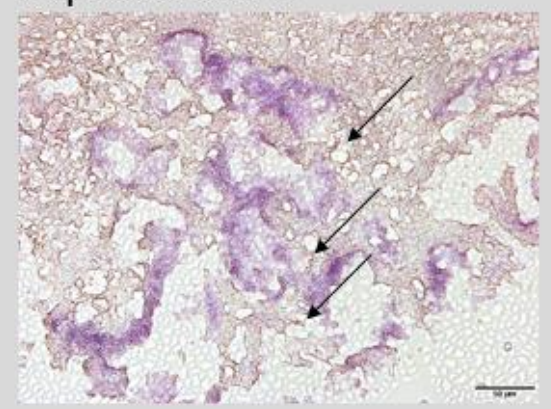

\section{Experimento 2}

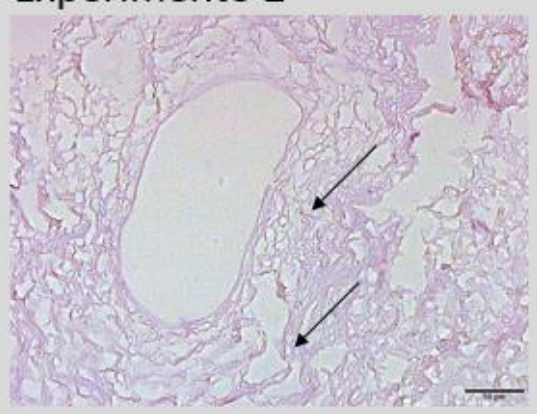

Figura 23. Grupo 6 - Elevado número de células apoptóticas no ensaio com fator de crescimento transformador beta exossomos e baixo índice de morte celular na sua repetição

Portanto, a recelularização de matriz porcina com células renais humanas é possível. Os exossomos determinam maior migração das células para estruturas renais além de conferir menor morte celular. 


\section{DISCUSSÃO}

O processo de recelularização tem sido descrito como uma técnica possível para a restauração da funcionalidade de órgãos mesmo depois de injúria ou de danos celulares.

Segundo Mao et al., a característica estrutural do órgão está intrinsecamente conectada com a sua função, logo a capacidade de recriação da estrutura do órgão é essencial para o sucesso na reobtenção de um tecido saudável. Os métodos executados no projeto, descelularização e, logo em seguida, recelularização, trazem uma das estratégias da engenharia de tecidos que é remover as células, porém conservando a estrutura da matriz extracelular nativa. ${ }^{(66)}$

$O$ presente estudo investigou a influência dos exossomos na recelularização, utilizando células renais humanas e fatores de crescimento, como HGF e TGF- $\beta$, no tecido renal porcino descelularizado.

Observamos a presença das células renais primárias na matriz previamente descelularizada na maioria das amostras. Quando inseridos os exossomos, maior número de células foram encontradas na matriz, bem como estruturas foram recelularizadas e menor morte celular ocorreu em grupos do experimento onde os exossomos estavam presentes.

Exossomos associaram-se positivamente com a recelularização. Nossos resultados estão de acordo com a literatura, Pashoutan et al., demonstraram que exossomos derivados de células-tronco mesenquimais aceleram a regeneração muscular via miogênese e angiogênese, ou seja, a presença de exossomos potencializou a recelularização em modelo animal. ${ }^{(30)}$

Nenhum experimento foi descrito na literatura com uso de exossomos em recelularização ex vivo. A injeção intravenosa de vesículas extracelulares oriundas de células-tronco mesenquimais de cordão umbilical tem evidenciado um "efeito renoprotetivo" proporcionando a regeneração tecidual através da redução de dano tecidual e apoptose, contribuindo para o reparo celular e consequente melhora da função renal em modelos animais de doença renal. ${ }^{(67,68)}$

$\mathrm{Na}$ literatura, estudos demonstram que exossomos promoveram efeitos antiapoptótico e anti-inflamatório no sistema cardiovascular, regeneração cardíaca, neovascularização e remodelação antivascular e anticardíaca. No sistema 
muscular, eles aceleraram a regeneração através dos processos de miogênese e angiogênese. No sistema nervoso, mesmo depois de um acidente vascular encefálico, a neurogênese foi aumentada juntamente com a remodelação dos neurônios e a angiogênese, demonstrando que os exossomos exercem um efeito neuroprotetor, visto que eles conseguem atravessar a barreira hematoencefálica com facilidade. ${ }^{(69-71)}$ No sistema renal, os exossomos tem o poder de proteger o rim contra danos isquêmicos com diminuição da resposta inflamatória e de apoptose em modelos animais. ${ }^{(72)}$ Em nosso estudo observamos que a presença de exossomos apresentou efeito equivalente, representado pela recelularização da matriz e da menor evidência de apoptose nos grupos com exossomos.

Considerando o Grupo G1 (matriz descelularizada + células renais humanas) como controle, uma vez que apenas células e matriz estavam presentes pudemos comparar os efeitos dos exossomos e de fatores de crescimento. Assim quando comparados ao G2 (matriz descelularizada + células renais humanas + exossomos), observou-se em G1 uma quantidade menor de células que a encontrada no G2. Os exossomos provavelmente participam de muitos dos processos fisiológicos e patológicos. Estes achados vãos de encontro à literatura, exossomos carreiam no seu interior fatores que chegam às células alvo. ${ }^{(30)}$ Outra importante observação é a localização das células, houve uma migração maior das células renais para o interior da matriz no G2, em comparação com o G1. O tamanho em nanômetros dos exossomos permite a sua facilidade de locomoção pela matriz extracelular, bem como a natureza do seu material, que não é de caráter sintético, o que exerce uma possibilidade de maior aceitação pela matriz.

O aumento da quantidade de células na matriz recelularizada que recebeu exossomos demonstrou o efeito dos exossomos na mitose e aderência celular. Esse efeito na recelularização provavelmente se deve à um efeito semelhante ao que ocorre na embriogênese, quando o HGF está implicado na diferenciação celular renal. No presente estudo, este efeito foi comprovado pela proliferação celular quando HGF foi adicionado à matriz porcina que foi recelularizada com células renais humanas (G3). A migração das células primárias renais aconteceu de forma mais acelerada para 0 centro da matriz comparando com as amostras sem a presença de HGF, tornando-se visível que o HGF é uma ferramenta importante na recelularização do tecido renal.

Comparando-se os grupos G1 (matriz descelularizada + células renais humanas) e G3 (matriz descelularizada + células renais humanas + HGF), houve 
migração das células em ambas as amostras. A amostra estimulada pelo fator HGF, o G3, demonstrou melhores resultados de recelularização, o que vai de encontro com a literatura uma vez que o HGF é um fator que está intimamente ligado ao processo da nefrogênese. ${ }^{(66,73)}$

Ju et al. mostraram em seu estudo que o HGF consegue promover a aceleração, recuperação e proliferação de células tubulares, mesmo após insulto, logo o processo de recelularização foi potencializado graças à presença do HGF. ${ }^{(34)}$

A associação de HGF e exossomos (avaliada no Grupo 4) quando comparada a G1 (matriz descelularizada + células renais humanas) demonstrou resultados dependentes dos doadores. Quando o experimento um foi realizado em triplicata, todas as amostras apresentaram crescimento celular e não houve morte celular. Quando outro doador foi utilizado não houve recelularização do fragmento. É possível que exossomos e HGF tenham sua ação dependente da capacidade celular de regeneração.

lekushi et al. demonstraram o TGF- $\beta$ como um dos antagonistas mais conhecidos do HGF, bem como o HGF é relatado por neutralizar a ação profibrótica de do TGF- $\beta$ por diferentes meios de sinalização em células renais. A presença de TGF- $\beta$ nos experimentos permitiu a aderência e migração celular, entretanto, as células eram apoptóticas. ${ }^{(74)}$

A comparação do Grupo G1 (matriz descelularizada + células renais humanas), com o Grupo G6 (matriz descelularizada + células renais humanas + TGF- $\beta$ + exossomos), comprova o efeito negativo do TGF- $\beta$. O TGF- $\beta$ é um fator próapoptótico e a possível combinação deste fator com os exossomos pode ter evitado a migração das células para o interior do tecido, o que causou a não recelularização do tecido renal. ${ }^{(66,73)}$

Ocorreu menor presença de células apoptóticas em experimentos com exossomos, o que sugere que os mesmos estejam envolvidos diretamente na aderência e sobrevivência das células renais humanas na matriz descelularizada. Quando o TGF- $\beta$ foi adicionado, as células renais humanas que conseguiram aderir a matriz localizaram-se em bordas e não migraram para a parte mais interior da matriz. Estas células eram apoptóticas após nove dias em cultura. Nos experimentos com HGF houve maior recelularização e menor apoptose. 
A associação de exossomos e fatores de crescimento foram dependentes das células mostrando uma provável comunicação celular, entretanto mais complexa, que não foi escopo desta análise.

A recelularização de matriz com células renais humanas é possível e os exossomos de células mesenquimais de cordão umbilical humano são facilitadores desta recelularização e diminuem morte celular. A avaliação das células renais humanas que se aderiram à matriz descelularizada porcina foi positiva e entendeu-se que apesar da utilização de uma matriz oriunda de espécie suína, houve uma compatibilidade entre as células humanas e a matriz. É nítida a grande influência do papel, tanto dos exossomos, quanto do HGF, exercendo um papel potencializador da adesão, proliferação e sobrevivência das células renais humanas.

O processo de recelularização através do uso de exossomos é um passo importante e fundamental para a medicina regenerativa. Os resultados foram substanciais, mas ainda assim precisa-se de mais estudos na área para avanço na perspectiva de soluções in vivo. 


\section{CONCLUSÕES}

1. A presença de exossomos aumenta a migração de células renais humanas às regiões mais centrais da matriz porcina descelularizada;

2. Células renais aderem à matriz com melhor eficiência na presença de exossomos e do fator de crescimento de hepatócitos;

3. Os exossomos de células mesenquimais de cordão umbilical humano diminuem a morte celular das células renais humanas na matriz porcina. 


\section{REFERÊNCIAS}

1. Kumar V, Abbas AK, Fausto N, Aster J. Robbins and Cotran pathologic basis of disease. 8th ed. Philadelphia: Saunders; 2010.

2. Menon V, Gul A, Sarnak MJ. Cardiovascular risk factors in chronic kidney disease. Kidney Int. 2005;68(4):1413-8.

3. Ikizler TA. CKD classification: time to move beyond KDOQI. J Am Soc Nephrol. 2009;20(5):929-30.

4. United States Renal Data System. Mortality and causes of death [Internet]. USA: United States Renal Data System; 2017 [cited 2018 Oct 25]. Available from:

https://www.usrds.org/reference.aspx

5. Sociedade Brasileira de Nefrologia. Censo da Sociedade Brasileira de Nefrologia [Internet]. São Paulo: SBN; 2017 [citado 2018 Out 25]. Disponível em: http://www.censo-sbn.org.br

6. Jha V, Garcia-Garcia G, Iseki K, Li Z, Naicker S, Plattner B, et al. Chronic kidney disease: global dimension and perspectives. Lancet. 2013;382(9888):260-72.

7. Mackensen-Haen S, Bohle A, Christensen J, Wehrmann M, Kendziorra H, Kokot F. The consequences for renal function of widening of the interstitium and changes in the tubular epithelium of the renal cortex and outer medulla in various renal diseases. Clin Nephrol. 1992;37(2):70-7.

8. Forino M, Torregrossa R, Ceol M, Murer L, Della Vella M, Del Prete D, et al. TGFbeta1 induces epithelial-mesenchymal transition, but not myofibroblast transdifferentiation of human kidney tubular epithelial cells in primary culture. Int J Exp Pathol. 2006;87(3):197-208.

9. Bedi S, Vidyasagar A, Djamali A. Epithelial-to-mesenchymal transition and chronic allograft tubulointerstitial fibrosis. Transplant Rev (Orlando). 2008;22(1):1-5.

10. Zavadil J, Böttinger EP. TGF-beta and epithelial-to-mesenchymal transitions. Oncogene. 2005;24(37):5764-74.

11. Baczkowska T, Perkowska-Ptasińska A, Sadowska A, Lewandowski Z, Nowacka-Cieciura E, Cieciura T, et al. Serum TGF-beta1 correlates with chronic histopathological lesions in protocol biopsies of kidney allograft recipients. Transplant Proc. 2005;37(2):773-5.

12. Fan JM, Huang XR, Ng YY, Nikolic-Paterson DJ, Mu W, Atkins RC, et al. Interleukin-1 induces tubular epithelial-myofibroblast transdifferentiation through a transforming growth factor-beta1-dependent mechanism in vitro. Am J Kidney Dis. 2001;37(4):820-31.

13. Docherty NG, O'Sullivan OE, Healy DA, Murphy M, O'neill AJ, Fitzpatrick JM, et al. TGFbeta1-induced EMT can occur independently of its proapoptotic effects and is aided by EGF receptor activation. Am J Physiol Renal Physiol. 2006;290(5):F1202-12.

14. Strutz F, Müller GA. Renal fibrosis and the origin of the renal fibroblast. Nephrol Dial Transplant. 2006;21(12):3368-70.

15. Cheng S, Lovett DH. Gelatinase A (MMP-2) is necessary and sufficient for renal tubular cell epithelial-mesenchymal transformation. Am J Pathol. 2003;162(6):1937-49. 
16. Oldfield MD, Bach LA, Forbes JM, Nikolic-Paterson D, McRobert A, Thallas V, et al. Advanced glycation end products cause epithelial-myofibroblast transdifferentiation via the receptor for advanced glycation end products (RAGE). J Clin Invest. 2001;108(12):1853-63.

17. Rhyu DY, Yang Y, Ha H, Lee GT, Song JS, Uh ST, et al. Role of reactive oxygen species in TGF-beta1-induced mitogen-activated protein kinase activation and epithelial-mesenchymal transition in renal tubular epithelial cells. J Am Soc Nephrol. 2005;16(3):667-75.

18. Yang J, Dai C, Liu Y. Hepatocyte growth factor gene therapy and angiotensin II blockade synergistically attenuate renal interstitial fibrosis in mice. J Am Soc Nephrol. 2002;13(10):246477.

19. Manotham K, Tanaka T, Matsumoto M, Ohse T, Inagi R, Miyata T, et al. Transdifferentiation of cultured tubular cells induced by hypoxia. Kidney Int. 2004;65(3):871-80.

20. Mason C, Dunnill P. A brief definition of regenerative medicine. Regen Med. 2008;3(1):1-5.

21. Uematsu K, Hattori K, Ishimoto Y, Yamauchi J, Habata T, Takakura Y, et al. Cartilage regeneration using mesenchymal stem cells and a three-dimensional poly-lactic-glycolic acid (PLGA) scaffold. Biomaterials. 2005;26(20):4273-9.

22. Wu YC, Shaw SY, Lin HR, Lee TM, Yang CY. Bone tissue engineering evaluation based on rat calvaria stromal cells cultured on modified PLGA scaffolds. Biomaterials. 2006;27(6):896904.

23. Pittenger MF, Mackay AM, Beck SC, Jaiswal RK, Douglas R, Mosca JD, et al. Multilineage potential of adult human mesenchymal stem cells. Science. 1999;284(5411):143-7.

24. Bydlowski SP, Debes AA, Maselli LM, Janz FL. [Biological characteristics of mesenchymal stem cells]. Rev Bras Hematol Hemoter. 2009;31 Suppl 1:25-35. Portuguese.

25. Horwitz EM, Le Blanc K, Dominici M, Mueller I, Slaper-Cortenbach I, Marini FC, et al.; International Society for Cellular Therapy. Clarification of the nomenclature for MSC: The International Society for Cellular Therapy position statement. Cytotherapy. 2005;7(5):393-5.

26. Monteiro BS, Argolo Neto NM, Del Carlo RJ. [Mesenchymal stem cell]. Cienc Rural. 2010;40(1):238-45. Portuguese.

27. Nauta AJ, Fibbe WE. Immunomodulatory properties of mesenchymal stromal cells. Blood. 2007;110(10):3499-506.

28. da Silva Meirelles L, Caplan AI, Nardi NB. In search of the in vivo identity of mesenchymal stem cells. Stem Cells. 2008;26(9):2287-99.

29. Patel SA, Sherman L, Munoz J, Rameshwar P. Immunological properties of mesenchymal stem cells and clinical implications. Arch Immunol Ther Exp (Warsz). 2008;56(1):1-8.

30. Pashoutan Sarvar D, Shamsasenjan K, Akbarzadehlaleh P. Mesenchymal stem cell-derived exosomes: new opportunity in cell-free therapy. Adv Pharm Bull. 2016;6(3):293-9.

31. Bruno S, Grange C, Deregibus MC, Calogero RA, Saviozzi S, Collino F, et al. Mesenchymal stem cell-derived microvesicles protect against acute tubular injury. J Am Soc Nephrol.

2009;20(5):1053-67. 
32. Kunter U, Rong S, Djuric Z, Boor P, Müller-Newen G, Yu D, et al. Transplanted mesenchymal stem cells accelerate glomerular healing in experimental glomerulonephritis. J Am Soc Nephrol. 2006;17(8):2202-12.

33. Zhu Z, Fang Z, Hu X, Zhou S. MicroRNAs and mesenchymal stem cells: hope for pulmonary hypertension. Rev Bras Cir Cardiovasc. 2015;30(3):380-5.

34. Ju GQ, Cheng J, Zhong L, Wu S, Zou XY, Zhang GY, et al. Microvesicles derived from human umbilical cord mesenchymal stem cells facilitate tubular epithelial cell dedifferentiation and growth via hepatocyte growth factor induction. PLoS One. 2015;10(3):e0121534.

35. Kim SS, Park HJ, Han J, Gwak SJ, Park MH, Song KW, et al. Improvement of kidney failure with fetal kidney precursor cell transplantation. Transplantation. 2007;83(9):1249-58.

36. Morigi M, Benigni A. Mesenchymal stem cells and kidney repair. Nephrol Dial Transplant. 2013;28(4):788-93.

37. Gilpin A, Yang Y. Decellularization strategies for regenerative medicine: from processing techniques to applications. Biomed Res Int. 2017;2017:9831534.

38. VeDepo MC, Detamore MS, Hopkins RA, Converse GL. Recellularization of decellularized heart valves: progress toward the tissue-engineered heart valve. J Tissue Eng.

2017;8:2041731417726327.

39. Sullivan DC, Mirmalek-Sani SH, Deegan DB, Baptista PM, Aboushwareb T, Atala A, et al. Decellularization methods of porcine kidneys for whole organ engineering using a highthroughput system. Biomaterials. 2012;33(31):7756-64.

40. Schor N. Bases moleculares da nefrologia. São Paulo: Atheneu; 2004.

41. Zatz, R. Bases fisiológicas da nefrologia. São Paulo: Atheneu; 2012.

42. Silverthorn DU. Fisiologia humana: uma abordagem integrada. 2a ed. Barueri: Manole; 2003.

43. Koeppen BM, Stanton BA. Renal physiology. 3rd ed. Saint Louis: Mosby; 2001.

44. Inker LA, Astor BC, Fox CH, Isakova T, Lash JP, Peralta CA, et al. KDOQI US commentary on the $2012 \mathrm{KDIGO}$ clinical practice guideline for the evaluation and management of CKD. Am J Kidney Dis. 2014;63(5):713-35.

45. Ishibe S, Cantley LG. Epithelial-mesenchymal-epithelial cycling in kidney repair. Curr Opin Nephrol Hypertens. 2008;17(4):379-85.

46. Kramann R, Kusaba T, Humphreys BD. Who regenerates the kidney tubule? Nephrol Dial Transplant. 2015;30(6):903-10.

47. Liu J, Krautzberger AM, Sui SH, Hofmann OM, Chen Y, Baetscher M, et al. Cell-specific translational profiling in acute kidney injury. J Clin Invest. 2014;124(3):1242-54. Erratum in: J Clin Invest. 2014;124(5):2288. Humphreys, Benjamin [corrected to Humphreys, Benjamin D].

48. Humphreys BD, Valerius MT, Kobayashi A, Mugford JW, Soeung S, Duffield JS, et al. Intrinsic epithelial cells repair the kidney after injury. Cell Stem Cell. 2008;2(3):284-91. 
49. Humphreys BD. Kidney injury, stem cells and regeneration. Curr Opin Nephrol Hypertens. 2014;23(1):25-31.

50. Broekema M, Harmsen MC, van Luyn MJ, Koerts JA, Petersen AH, van Kooten TG, et al. Bone marrow-derived myofibroblasts contribute to the renal interstitial myofibroblast population and produce procollagen I after ischemia/reperfusion in rats. J Am Soc Nephrol. 2007;18(1):165-75.

51. Lange C, Tögel F, Ittrich H, Clayton F, Nolte-Ernsting C, Zander AR, et al. Administered mesenchymal stem cells enhance recovery from ischemia/reperfusion-induced acute renal failure in rats. Kidney Int. 2005;68(4):1613-7

52. Tögel F, Hu Z, Weiss K, Isaac J, Lange C, Westenfelder C. Administered mesenchymal stem cells protect against ischemic acute renal failure through differentiation-independent mechanisms. Am J Physiol Renal Physiol. 2005;289(1):F31-42.

53. Lazzeri E, Crescioli C, Ronconi E, Mazzinghi B, Sagrinati C, Netti GS, et al. Regenerative potential of embryonic renal multipotent progenitors in acute renal failure. J Am Soc Nephrol. 2007;18(12):3128-38.

54. Sagrinati C, Netti GS, Mazzinghi B, Lazzeri E, Liotta F, Frosali F, et al. Isolation and characterization of multipotent progenitor cells from the Bowman's capsule of adult human kidneys. J Am Soc Nephrol. 2006;17(9):2443-56.

55. Herrera MB, Bussolati B, Bruno S, Morando L, Mauriello-Romanazzi G, Sanavio F, et al. Exogenous mesenchymal stem cells localize to the kidney by means of CD44 following acute tubular injury. Kidney Int. 2007;72(4):430-41.

56. Kato S, Chmielewski M, Honda H, Pecoits-Filho R, Matsuo S, Yuzawa Y, et al. Aspects of immune dysfunction in end-stage renal disease. Clin J Am Soc Nephrol. 2008;3(5):1526-33.

57. Molnar MZ, Carrero JJ, Mucsi I, Remport A, Rhee CM, Kalantar-Zadeh K, et al. Comparison of the malnutrition-inflammation score in chronic kidney disease patients and kidney transplant recipients. Int Urol Nephrol. 2015;47(6):1025-33.

58. Grabulosa CC. Expressão do receptor toll like 4, citocinas e catelicidina em neutrófilos e monócitos de pacientes com doença renal crônica [tese]. São Paulo: Universidade Federal de São Paulo; 2017.

59. Uygun BE, Soto-Gutierrez A, Yagi H, Izamis ML, Guzzardi MA, Shulman C, et al. Organ reengineering through development of a transplantable recellularized liver graft using decellularized liver matrix. Nat Med. 2010;16(7):814-20.

60. Crabbé A, Liu Y, Sarker SF, Bonenfant NR, Barrila J, Borg ZD, et al. Recellularization of decellularized lung scaffolds is enhanced by dynamic suspension culture. PLoS One. 2015;10(5):e0126846.

61. Tsuchiya T, Sivarapatna A, Rocco K, Nanashima A, Nagayasu T, Nicklason LE. Future prospects for tissue engineered lung transplantation: decellularization and recellularizationbased whole lung regeneration. Organogenesis. 2014;10(2):196-207.

62. Ross EA, Williams MJ, Hamazaki T, Terada N, Clapp WL, Adin C, et al. Embryonic stem cells proliferate and differentiate when seeded into kidney scaffolds. J Am Soc Nephrol. 2009;20(11):2338-47. 
63. Song JJ, Guyette JP, Gilpin SE, Gonzalez G, Vacanti JP, Ott HC. Regeneration and experimental orthotopic transplantation of a bioengineered kidney. Nat Med. 2013;19(5):64651.

64. Ko IK, Abolbashari M, Huling J, Kim C, Mirmalek-Sani SH, Moradi M, et al. Enhanced reendothelialization of acellular kidney scaffolds for whole organ engineering via antibody conjugation of vasculatures. Technology (Singap World Sci). 2014;2(3):243-53.

65. Caralt M, Uzarski JS, lacob S, Obergfell KP, Berg N, Bijonowski BM, et al. Optimization and critical evaluation of decellularization strategies to develop renal extracellular matrix scaffolds as biological templates for organ engineering and transplantation. Am J Transplant. 2015;15(1):6475. Erratum in: Am J Transplant. 2017;17(5):1429.

66. Mao AS, Mooney DJ. Regenerative medicine: current therapies and future directions. Proc Natl Acad Sci U S A. 2015;112(47):14452-9.

67. Gatti S, Bruno S, Deregibus MC, Sordi A, Cantaluppi V, Tetta C, et al. Microvesicles derived from human adult mesenchymal stem cells protect against ischaemia-reperfusion-induced acute and chronic kidney injury. Nephrol Dial Transplant. 2011;26(5):1474-83.

68. Wang R, Lin M, Li L, Li L, Qi G, Rong R, et al. [Bone marrow mesenchymal stem cellderived exosome protects kidney against ischemia reperfusion injury in rats]. Zhonghua Yi Xue Za Zhi. 2014;94(42):3298-303. Chinese.

69. Huang L, Ma W, Ma Y, Feng D, Chen H, Cai B. Exosomes in mesenchymal stem cells, a new therapeutic strategy for cardiovascular diseases? Int J Biol Sci. 2015;11(2):238-45.

70. Nakamura Y, Miyaki S, Ishitobi H, Matsuyama S, Nakasa T, Kamei N, et al. Mesenchymalstem-cell-derived exosomes accelerate skeletal muscle regeneration. FEBS Lett.

2015;589(11):1257-65.

71. Jarmalavičiūtè A, Pivoriūnas A. Exosomes as a potential novel therapeutic tools against neurodegenerative diseases. Pharmacol Res. 2016;113(Pt B):816-22.

72. Aghajani Nargesi A, Lerman LO, Eirin A. Mesenchymal stem cell-derived extracellular vesicles for kidney repair: current status and looming challenges. Stem Cell Res Ther. 2017;8(1):273.

73. Farris $A B$, Colvin RB. Renal interstitial fibrosis: mechanisms and evaluation. Curr Opin Nephrol Hypertens. 2012;21(3):289-300.

74. lekushi K, Taniyama Y, Kusunoki H, Azuma J, Sanada F, Okayama K, et al. Hepatocyte growth factor attenuates transforming growth factor- $\beta$-angiotensin II crosstalk through inhibition of the PTEN/Akt pathway. Hypertension. 2011;58(2):190-6. 


\begin{abstract}
Introduction: Chronic kidney disease became a worldwide growing problem in the last decades. The kidney has the ability to regenerate almost completely after insults. However, in some situations, progressive fibrosis with functional loss occurs. Some growth factors have been described such as hepatocyte growth factor (HGF), which is an important regulator of renal cell recovery. Recent studies suggest a mechanism of cellular communication between mesenchymal stem cells and renal epithelial cells, and report the presence of HGF inside the exosomes suggesting that HGF is a stimulatory mechanism for tissue regeneration. Purpose: To evaluate the effect of exosomes from umbilical mesenchymal stem cells on the adherence and proliferation of primary renal cells cultured in a decellularized renal matrix. Methods: The evaluation was carried out in stages: characterization of human renal cells in culture, obtaining exosomes from umbilical cord mesenchymal stem cells and characterization of exosomes by the use of western blot (CD63 and CD81); and porcine kidney decellularization by the use of sodium dodecyl sulfate decellularization method. Recellularization was performed by comparing and isolating effect of exosomes in the presence of pro-growth factor like HGF and pro-fibrosis factor like transforming growth factor beta (TGF- $\beta$ ). Results: Human kidney cells had satisfactory growth in cultures. Decellularized porcine kidney tissue preserved the architecture. Exosomes from mesenchymal stem cells were secreted and positively characterized for CD63 and CD81 in western blot. Recellularization showed by the adhesion of renal cells occurred in all experiments. When we evaluated cell death through caspase 3 , the association of TGF- $\beta$ and exosomes determined a higher percentage of apoptotic cells. In the other experiments the presence of the exosomes determined lower cell death. Conclusion: Exosomes produced by human umbilical cord mesenchymal stem cells induced lower cell death in matrix recellularization with human kidney cells.
\end{abstract}

